Portland State University

PDXScholar

6-8-2021

\title{
Towards a Theory of Informal Supply Networks: an Exploratory Case Study of the Za'atari Refugee Camp
}

Ismail Abushaikha

German-Jordanian University

Zhaohui Wu

Oregon State University

Theodore A. Khoury

Portland State University, tedkhoury@pdx.edu

Follow this and additional works at: https://pdxscholar.library.pdx.edu/busadmin_fac

Part of the Business Commons

Let us know how access to this document benefits you.

\section{Citation Details}

Abushaikha, I., Wu, Z., \& Khoury, T. A. (2021). Towards a theory of informal supply networks: An exploratory case study of the Za'atari refugee camp. Journal of Operations Management, joom.1151. https://doi.org/10.1002/joom.1151

This Post-Print is brought to you for free and open access. It has been accepted for inclusion in Business Faculty Publications and Presentations by an authorized administrator of PDXScholar. Please contact us if we can make this document more accessible: pdxscholar@pdx.edu. 


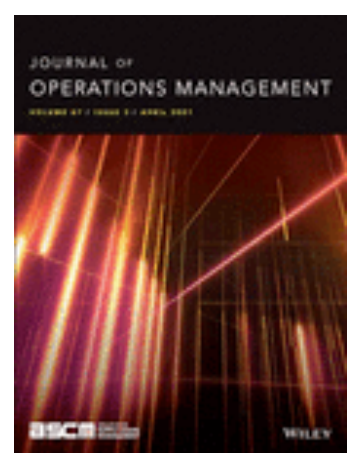

\title{
Towards a Theory of Informal Supply Networks: An Exploratory Case Study of the Za'atari Refugee Camp
}

\author{
Ismail Abushaikha Ph.D. \\ German-Jordanian University \\ Ammab Madaba Street \\ P.O.Box 35247 \\ Amman 11180 Jordan \\ ismail.abushaikha@gju.edu.jo \\ Zhaohui $\mathrm{Wu}^{*} \mathrm{Ph} . \mathrm{D}$. \\ Supply Chain Management \\ College of Business \\ Oregon State University \\ Corvallis, OR 97331 \\ wuz@oregonstate.edu \\ Theodore A. Khoury Ph.D. \\ The School of Business, \\ Portland State University \\ Portland, OR 97201 \\ tkhoury@pdx.edu
}

*Corresponding author

Please cite as:

Abushaika, I., Wu, Z., Khoury, T.A., (2021) Towards a theory of informal supply networks: An exploratory case study of the Za'atari refugee camp. Journal of Operations Management. doi: 10.1002/joom. 1151 
Acknowledgments. We are grateful to the refugees, organizations, and communities that helped us to realize this study. We are particularly thankful to Mercy Corps and United Nations World Food Program (WFP) for their assistance within the Za'atari Camp.

We also thank the four anonymous reviewers, the associate editor, and the department editor, who provided us with expert guidance and critique throughout the review process. We would also like to acknowledge the help we received from our colleagues, Alison Minkus and Paul Skilton, who provide valuable feedback. Lastly, we thank audience participants who provided comments and critiques on early stage of this work at the 2017 POMS and 2019 EGOS conferences and seminars at École du Management Grenoble, University of York, and University of Sussex. Theodore Khoury thanks Vlerick Business School for hosting him as a visiting scholar while conducting this research. 


\title{
Towards a Theory of Informal Supply Networks: An Exploratory Case Study of the Za'atari Refugee Camp
}

\begin{abstract}
Studies of humanitarian supply chain operations contribute to efficient system designs for the delivery of goods and services to disaster- and conflict-stricken regions. However, our understanding of what happens to these relief goods and services after they are delivered is quite limited. Using a case study of the Za'atari refugee camp in Jordan, we develop a theory of informal supply networks, whereby we uncover how refugee-led, informal supply networks emerge in the camp. We find that these supply networks are an aggregate of predominantly illicit - yet legitimate — channels and social relationships that support the economic exchange of goods and services between distinct actors or actor groups. We not only identify the cultural conventions and behavioral codes that govern ties between refugees — and between refugees and relief-related actors-but also define how these networks are configured. Considering these findings, we contend that the informal economic activities emanating from the refugee camp benefit the host community and enhance the resilience of the informal supply networks. As informal economic activities also improve the quality of life in the camp, camp authorities and host country governments should attend to informal activities as they create rules and policies for refugee resettlement.
\end{abstract}

Key words: humanitarian relief operations, disaster science, informal supply networks, informal economies, network resilience, refugee camp, UNHCR, case study, Syrian refugee, Za'atari refugee camp 


\section{Introduction}

Due to an escalating Syrian Civil War in 2011, refugee-related challenges quickly ascended to the top of the global political agenda. Today, there are approximately 65 million people who have been uprooted from their homes, more than any other time since World War II. Nearly a third of these have no alternative but to seek dangerous border crossings, and many of these find their way to sites where relief systems, such as refugee camps, are being deployed. However, integration challenges, unwillingness to support refugee populations, and rising nationalistic tendencies exist in many parts of the world (Collier \& Betts, 2017a). These realities prompt the study of humanitarian relief operations that support the successful integration of refugees into host communities.

Humanitarian relief operations increasingly represent a critical and timely area of research with a growing number of scholars focusing on logistics and tactical challenges of matching supply and demand in various disaster relief settings. We answer a call to examine system-level challenges (Pedraza-Martinez \& Wassenhove, 2016) that drive the causes and socioeconomic consequences of crises, as well as how these consequences are confronted over time. Tackling challenges, such as temporary, post-conflict refugee settlement, requires a deep understanding of human behavior among the various actor groups engaged in disaster-related settings (Drabek, 1986; Quarantelli, 1966).

We examine humanitarian relief operations in a Syrian refugee camp. Refugee camps represent complex social systems (Algier, 2002) that have important political, social, and economic consequences for host countries (Dunn, 2018). While there is an understanding of how 
goods are delivered to such disaster-stricken zones, there is little known about how humanitarian relief operations function inside refugee camps and how interactions develop among relief organizations, refugees, host communities and governments. We contend that scholarship in humanitarian relief operations should move beyond the study of optimizing supply chains for the delivery of crucial goods and services to supporting the quality of life of refugees through operations management.

While humanitarian relief operations inside refugee camps invariably involve refugees, the development patterns of refugee camps can vary as a result of the economic and social backgrounds of the refugees, as well as the connections (or lack thereof) of refugee groups with host communities (Alloush, Taylor, Gupta, Valdes, \& Gonzalez-Estrada, 2017; Arar, 2017; Kreibaum, 2016; Taylor et al., 2016; UNDP, 2015). Recent research has highlighted an inherent tension between the humanitarian principle of providing for the basic needs of a vulnerable population— by intergovernmental organizations (IGOs), such as the United Nations High Commissioner for Refugees (UNHCR or UN Refugee Agency) and the World Food Program (WFP), as well as non-governmental organizations (NGOs) contracted by IGOs - and the evolving economic and social development needs of refugees (Barnett, 2014). With increasingly longer stays becoming the norm (Collier \& Betts, 2017a,b; Loescher, 2017), host governments and communities often view refugees according to a real—or manipulated—fear of having to permanently support refugees in their communities (Anderson, 2013). Concerns about the economic, social, and political impact of refugees have often led to reluctant welcomes and a lack of integration in regional economies and labor forces. Prior research has also revealed that relief operations championed by the UNHCR are outdated and fail to account for recent, large- 
scale migration patterns of refugees throughout Europe and Asia (De Montclos \& Kagwanja, 2000; Pedraza-Martinez \& Wassenhove, 2016).

Since refugees are first uprooted and then confined to a foreign locale, refugee camps become settings where former social relations and norms are either fractured or temporarily suspended. However, camps - as physical locales - are not a social vacuum but rather spaces where refugees strive to engage in familiar cultural and economic practices. Such practices impact not only how the daily routines of life are experienced but also how economic stability is realized in the camp. When viewed as a system, these activities represent the types of operations undertaken by relief-related actors in refugee camps. The role that refugees play in shaping these operations represents an underexplored yet important area of research. Refugee camps should not only be viewed as a more or less permanent form of settlement within set physical and social boundaries but also places where refugees have agency to create their futures through economic exchange. Thus, we investigate how the economic activities of refugees shape the humanitarian relief operations inside a refugee camp.

As the current Syrian refugee crisis presents a rare opportunity for this type of research, we conducted a case study of the Za'atari refugee camp — the largest refugee camp in Jordanfrom the time of its establishment to its current form. Leveraging data collected in interviews (i.e., with focal camp stakeholders), from archival sources, and through direct field observations, we propose a theory of informal supply networks based on the activities of refugees and reliefrelated actors. 


\section{Literature}

2.1 The global refugee regime

Sudden and large refugee resettlement continues to be one of the most challenging humanitarian crises of the last decade (Jones, 2016). In response to large numbers of refugees fleeing Europe during World War II, the modern system of accounting for refugees emerged in the late 1940s and led to the creation of the Office of the UNHCR. The 1951 Convention Relating to the Status of Refugees — or the 1951 Refugee Convention—committed governments to provide protection and basic rights to people fleeing persecution in their home territories (Loescher, 2017; UNHCR, 2018a). The current global refugee regime and international humanitarian order represent the institutional structures that define boundaries of movement and the status of refugees, as well as the authority and responsibility of IGOs, NGOs, host governments, and communities (Agier, 2011; Collier \& Betts, 2017a; Sanyal, 2012).

As part of their function to represent an intergovernmental network, the UNHCR takes an emergency-oriented humanitarian approach in guiding refugees to a protected and safe - albeit temporary-place (Jahre et al., 2016). Therefore, the focal mission of the UNHCR is to provide refugees with critical emergency assistance, including clean water, food, shelter, sanitation services, basic medical care, and common consumable goods. In other words, the UNHCR supports short-term alleviation of suffering. In the founding statute (1950) of the UNHCR, refugee camps were set up as non-political entities that allowed the UNHCR to access refugees in areas of conflict and to provide sanctuary for both victims and aid workers.

More recently, refugee camps have also been set up to buffer citizens from refugees, with refugees kept at a physical — and symbolic_-distance from the host community (Agier, 2011; 
Collier \& Betts, 2017b; Dunn, 2018). By keeping refugees inside the camp, host governments assume that refugees—after a temporarily stay in the camp—will eventually return to their homelands. In reality, over half of these refugees endure protracted stays of more than two decades, and over 80 percent of camp refugees remain there for at least five years (UNHCR, 2018b,c; UNRWA, 2018). Outside the camp, freedom of movement is either prohibited or-at best - tightly controlled, and access to education and employment is highly constrained. Overall, there is little investment in the economic and social development needs of refugees (Kleinschmidt \& Sy, 2016). As a result, refugees remain in an in-between state due to imposed limitations that affect their access to an economic livelihood and to the social services afforded to the host community.

2.2 The informal economy and the refugee economy

The informal economy is defined as "the set of illegal yet legitimate activities through which actors [can] recognize and exploit opportunities" (Webb, Khoury, \& Hitt, 2020, p. 492). Along a continuum of informality (Williams \& Shahid, 2016), context (i.e., the cultural or legal frameworks of a locality) determines whether illicit, informal activities are accepted as legitimate, such as selling counterfeit shoes, or illegitimate, such as selling weapons (Webb, Tihanyi, Ireland, \& Sirmon, 2009).

Individuals participate in the informal economy when other options are unavailable (Fadahunsi \& Rosa, 2002) or when market access is not served by formal routes (Holt \& Littlewood, 2014). The tolerance for — and subsequent development of — the informal economy may also reflect traditions and customs that govern how transactions have been carried out in a particular context over time (Webb et al., 2020; Wilson, 2018). For example, the informal 
economy is especially prevalent in contexts that have placed a greater emphasis on intermediary roles within markets (Fadahunsi \& Rosa, 2002). Although hardly optimal in terms of operational efficiency, these roles do overcome obstacles imposed by security apparatuses (Khoury \& Prasad, 2016). The skills for this mode of market engagement, such as taking on an intermediary role, may be embedded within cultural norms (Webb et al., 2020).

An informal economy provides camp refugees with a livelihood when a formal economy is unavailable. In such a contained population, the informal economy is characterized by restricted mobility and restricted participation in markets outside the designated boundaries of the camp (Khoury \& Prasad, 2016; Werker, 2007). At the same time, the informal economy is structured as an institutional space where state and international regulations intersect. Exchanges that occur in this space can be evaluated along a continuum of enterprise informality (i.e., according to subjective degrees of legality or illicitness) where the legitimacy of informal exchange activities is contextually-defined (Webb et al., 2020). In the context of a refugee camp, refugees experience both opportunities and constraints (Oka, 2011), and relief organizations tolerate varying rules between those applied inside the camp and those held by host community.

Since the institutional contexts of refugee camps can vary substantially, there is no one typical refugee economy. For example, Syrian refugee camps in Jordan, Lebanon, and Turkey vary in how they are managed because the host countries have different geo-political goals, capabilities, resources, and ethnic connections with the refugees (Chatty, 2016). Likewise, some refugee camps, such as those for Palestinian refugees throughout Lebanon or Gaza, evolve into urban neighborhoods that have little prospect for formal economic opportunities. Ultimately, these ghettoized camps have endured seven decades of abysmal funding and neglect (Shepherd, 
Saade, \& Wincent, 2020). Despite these differences, researchers have recognized that refugee economies do not exist in isolation but are rather tied to market actors and entities in the host community and —at times—-those located abroad (Betts, Omata, \& Bloom, 2017; Chowdhury, 2020; Turner, 2005; UNHCR, 2017). While refugees are lured by economic opportunities beyond camp borders due to their dire situation, they are also subject to a complex management system inside the camp that affords authority to IGOs, NGOs, and local governments. This type of context raises the question of how informal economies emerge and take shape within and beyond refugee camps.

\subsection{Disaster science and humanitarian relief operations}

Rooted in sociology, the study of disaster science appeared in the U.S. in the late 1950s, when social scientists — with the support from military organizations - investigated how extreme stress impacted the social and psychological aspects of behavior, as well as how governments protected populations and effectively managed crises (Quarantelli, 1966). While early disaster science research had a clear focus on war-related disasters, many practical field studies were conducted in peacetime. These studies examined social behaviors during sudden natural disasters and extrapolated earlier learnings. Over more than 60 years, Quarantelli (1966) and other pioneers in disaster science research found that disasters brought out the best in humanity. Time and time again, disaster victims formed emergent organizations and had a heightened sense of kinship and camaraderie (Drabek, 1986; Rodríguez, Trainor, \& Quarantelli, 2006).

Since the 1980s, disaster science research has expanded to include slow-onset and chronic disasters, and it has shifted its focus from disaster planning to disaster management (Holguín-Veras, Jaller, Van Wassenhove, Pérez, \& Wachtendorf, 2012b; Quarantelli, 2005). 
Researchers have also highlighted the role of social capital in relief networks and stakeholder connections (Adger et al., 2005; Dynes, 2005; Nakagawa \& Shaw, 2004; Tatsuki, 2008). Following Lin (2008, p. 51), social capital is defined as "resources embedded in one's social networks, [and] resources that can be accessed or mobilized through ties in the networks." Disaster science scholars associate social capital with three forms of relationship ties—-bonding, bridging, and linking. These ties structure the relief network, which, in turn, connects disaster victims to different donors and resources (Aldrich, 2011; Prost, 2006).

In the absence of social capital, certain groups, such as isolated groups and newcomers to existing networks, can be excluded. Holguín-Veras, Jaller, \& Wachtendorf (2012a) examined humanitarian logistics structures to assess the effectiveness of resource deployment. They specified three types of logistics structures based on an in-depth analysis of humanitarian relief operations during the Haiti earthquake. During the relief effort, these logistics structures differed in terms of the level of integration between local social networks and external and internal relief organizations. These studies emphasize the importance of understanding relief supply networks and social networks that span across disaster zones.

In the last two decades, increasing natural and climate-related disasters — and their related disruptions - have drawn operations management scholars to investigate humanitarian relief operations (Pedraza-Martinez \& Wassenhove, 2016; Sanyal, 2012; Starr \& Van Wassenhove, 2014; UNHCR, 2009; UNHCR, 2017). One research agenda has focused on logistics and inventory solutions in disaster environments, which are often characterized by severe resource and time constraints, as well as information uncertainty. Gupta, Starr, Farahani, \& Matinrad (2016) argued that even though humanitarian relief operations account for both disaster response 
and program development most research studies focus on response, overlooking recovery, restoration, and development. Pedraza-Martinez \& Wassenhove (2016) also called for future studies that would attend to the complexities of managing an operational mix of response and development. One exception is Sodhi (2016), who explored disaster cycles in terms of the interplay between long-term development and short-term response.

After taking stock of recent studies in disaster science and humanitarian relief operations, we argue that investigating relief operations inside refugee camps is an important step in advancing a development-oriented research agenda. In refugee camps, the formal relief operations of IGOs/NGOs and host governments interact with the informal economic activities of refugees to build social-technical camp systems. Using an exploratory case study approach, we investigate how the economic activities of refugees enable operations, such as production and distribution, and build refugee economies in a refugee camp.

\section{Method}

\subsection{Research context and design}

Consistent with our core research question and assumptions, we employed an inductive research design (Glaser \& Strauss, 1967; Miles \& Huberman, 1994). Our choice of the Za'atari refugee camp was informed by previous single case studies on organizational networks (e.g., Browning, Beyer, \& Shetler, 1995; Obstfeld, 2005) and supply network research (e.g., Wu \& Pullman, 2015). Theoretical sampling depends upon the selection of a case that is either unusually revelatory or an extreme exemplar (Eisenhardt \& Graebner, 2007; Yin, 1994). Thus, we chose the Za'atari refugee camp as it is the second largest in the world, after the Dadaab Refugee Camp in Kenya (UNHCR, 2018b), and since it has various commonalities with - and 
distinctions from - other camps around the world. It is often profiled as a "success story" in the media and by relief organizations and donor countries, given its city-like settings and energetic marketplaces.

During the early years of the Syrian conflict, the lead author - a native of the regionwas located in Jordan, and the author team was positioned to secure research access to the camp through university and NGO relationships. The author team followed recommended guidelines regarding researcher (team) position and reflexivity with the focal subject and setting (Berger, 2015). Since the camp only included Syrian refugees, the author team was able to conduct the study with a sensitivity to the lives of these refugees - both prior to and following a forced migration to Jordan (Mackenzie, McDowell, \& Pittaway, 2007). For example, the lead authornative in Levantine Arabic 1 — had traveled to various border regions of Syria over the years prior to the conflict. Further, the lead author and another member of the author team were children of Palestinian refugees, growing up with a sensitivity to conflict-induced refugee narratives and experiencing direct socialization within communities of recent and former refugees. These advantages in language skills and personal experiences provided valuable perspectives when conducting interviews, capturing nuanced artifacts, and recognizing meaningful observations (Berger, 2015; Temple \& Edwards, 2002). Further, these attributes created a sense of approachability during interviews.

\subsection{Data collection}

Qualitative interview data were collected between January 2016 and September 2018, in addition to secondary data collected from 2012 to 2018. Data were collected from refugees in the

\footnotetext{
${ }^{1}$ Levantine Arabic is used throughout Syria and Jordan, as well as in Lebanon and Palestine.
} 
camp, residents of the host city of Al-Mafraq (henceforth, Mafraq), managers and staff members of IGOs/NGOs, and officials of the Jordanian government. As these groups represent the crucial actor groups in this emergency setting (Quarantelli, 1966), they are positioned in terms of their respective roles in the supply networks, policy making, and camp management.

Accessing the refugee camp and interviewing refugees often required improvised planning and flexibility. The approval process had strict procedures concerning who entered, when they entered, and how long they stayed in the camp. Based on a formal relationship created between the university of the lead author and the authorities at the camp (i.e., the local government and the UNHCR), as well as a working relationship of the third author with a prominent NGO actively working in social services support in the camp, access permits were granted on five occasions. The first field visit was granted through the UNHCR, while the remaining visits were enabled through an NGO. Following an entry request, notification of entry approval came suddenly and often unexpectedly the day prior. Since the lead author was stationed in Amman, Jordan-located 71 kilometers away from the camp, short-notice field visits were, however, achievable.

Each field visit lasted between seven and nine hours and involved stops at refugee-owned shops (e.g., offering food, basic goods, cell phones, perfume, clothing, and wedding gown rentals), camp-sanctioned supermarkets (e.g., Safeway and Tazweed), and NGO-established community centers. In addition to refugee camp visits, the lead author also spent two days in the host community of Mafraq, located ten kilometers from the camp. Finally, the lead author also participated in various refugee forums (e.g., symposiums, lectures, and events) in Amman during this time. Forum participants included the Jordanian government, more than 20 NGOs, and 
several IGOs. These events provided additional information on the interactions of these actors, as well as their activities in the camp, and the progress of their programs. Trips to the camp and host community involved direct observations, interviews, and participation in the daily activities of government security personnel, relief workers, NGOs/IGOs, and refugees.

Levantine Arabic was used for $85 \%$ of the interviews conducted in Jordan and English for all others. Different interview protocols were created for the various interviewee groups, and interview questions were open-ended to allow interviewees to describe processes and experiences according to their perceptions. Early interview data was translated, transcribed, and analyzed to uncover emerging, salient themes, as well as inform the selection of subsequent interview subjects or the collection of further archival data. The interview questionnaires were updated as the author team coded these data and new questions arose (see Appendix A for the interview protocol and a sample of the interview questions).

Interviewing potentially vulnerable subjects, such as refugees, who have escaped situations of crisis, disaster, or conflict, raises two critical issues (Pacheco-Vega \& Parizeau, 2018). First and foremost, the safety of interviewees could not be compromised by the author team. Thus, the identities of interviewees were protected by the author team through the strict control and storage of these data on password-encrypted drives and through the anonymization of all subjects. During and following interviews, subjects also knew that they could retract information or completely withdraw from the study at any time. Second, the ethnic, lingual, and social backgrounds of the author team supported a sensitivity to cultural nuances during the interviews, which — to our knowledge — did not invoke previous experiences of loss and trauma (Mackenzie et al., 2007). The backgrounds of the authors also helped the team to avoid viewing 
the context and subjects of the Levantine Middle Eastern culture through a Western lens (Said, 1978). While refugees were the focal actors in the study, their status was not objectified, and stigmas commonly associated with refugee narratives were not reproduced.

Interviews with $\mathrm{NGO} / \mathrm{IGO}$, Jordanian government officials and host community residents were usually organized directly with the interview subjects; however, interviews with refugees were coordinated through the NGO managers. Prior to the camp visits, NGO personnel helped select interviewees and arrange interview times. Snowball sampling — an approach often used in network-oriented studies (Prell, 2012)—created opportunities to meet with further interviewees, such as informal refugee retailers or residents of certain camp districts. While such interviews were unplanned, they helped clarify and triangulate information derived from other interviews, thus providing a richer understanding of the relationships among refugees and between refugees and other entities. A large number of interviews were sought to ensure theoretical saturation (Eisenhardt, 1989) and account for a variety of actor backgrounds. Following our data analysis, we also consulted various journalist accounts of the camp and the ethnographic dissertation of Dalal (2014, 2015), which helped triangulate several descriptive and contextual elements uncovered in the interviews and the observation data.

Interviews provided the most crucial and evidential data for this study. A total of $52 \mathrm{semi-}$ structured interviews (i.e., 44 in Levantine Arabic and eight in English) were conducted, with approximately $95 \%$ undertaken by the lead author. In addition to 31 interviews conducted inside the camp, a further 14 were conducted in Amman, six in the city of Mafraq, and two in Kathmandu, Nepal. ${ }^{2}$ One interview with a former UNHCR official, who was in charge of the

\footnotetext{
2 The interviews in Nepal were conducted in English with two NGO workers from the Za' atari refugee camp who
} were in Nepal for workshop training with one of the authors in February 2018. 
camp in its early years, was conducted over Skype with the author team. Interviews in the camp took place in settings considered safe by the refugees, such as in a facility or structure affiliated with an IGO/NGO and, in some instances, in marketplace shops and caravans where the refugees lived. During two of these visits, the lead author was accompanied by a graduate research assistant who helped take interview and field notes. Consent to digitally record the interviews was received from 30 of the 52 interviewees. When taping was not permitted, detailed notes were taken during and shortly after the interview. Field notes were also taken during all camp visits. All interviews conducted in Arabic were translated into English within five days of the interview. The author team also conducted online calls within three days of a field visit to discuss and further expand a retrospective account of the visit and the interviews. Table 1 lists the interviewees, the interviewee backgrounds, and the interview sites, durations, and languages.

During the camp visits when interviews were conducted, observation data and field notes were also collected. Further, approximately 200 photographs and 20 videos were collected during walks and drives through various camp districts to document the physical infrastructure of the camp and the routine activities of the refugees. The field visits to the camp and host community also revealed how the supply network was impacted by the context. 
Table 1

Interview summary.

\begin{tabular}{|c|c|c|}
\hline Interviewee & Interviewee Background & $\begin{array}{l}\text { Interview Site, Duration } \\
\text { (in minutes), and Language }\end{array}$ \\
\hline Mafraq host community & $\begin{array}{l}\text { Bike shop owner } \\
\text { Kiosk owner } \\
\text { Supermarket cashier } \\
\text { Mafraq-based university student }\end{array}$ & $\begin{array}{l}\text { Mafraq, 50, Arabic } \\
\text { Mafraq, 40, Arabic } \\
\text { Mafraq, 45, Arabic } \\
\text { Mafraq, 45, Arabic }\end{array}$ \\
\hline Government & $\begin{array}{l}\text { Camp community police officer \#1 } \\
\text { Camp community police officer \#2* } \\
\text { Government liaison officer with IGOs } \\
\text { Government liaison officer with NGOs } \\
\text { Government official \#1, Ministry of Interior } \\
\text { Government official \#2, Ministry of Interior } \\
\text { Country coordinator of NGOs } \\
\text { Camp court lawyer }\end{array}$ & $\begin{array}{l}\text { Za'atari refugee camp, 40, Arabic } \\
\text { Za'atari refugee camp, 50, Arabic } \\
\text { Amman, 50, Arabic } \\
\text { Amman, 45, Arabic } \\
\text { Amman, 55, Arabic } \\
\text { Amman, 35, Arabic } \\
\text { Amman, 50, English } \\
\text { Za'atari refugee camp, 45, Arabic }\end{array}$ \\
\hline NGO/IGO & $\begin{array}{l}\text { Camp field worker, NGO-A } \\
\text { Camp field worker, UNHCR } \\
\text { Camp site supervisor, NGO-C } \\
\text { Child protection officer \#1, NGO-B } \\
\text { Child protection officer \#2, NGO-B } \\
\text { Camp operations driver, NGO-A } \\
\text { Camp former director \#1 } \\
\text { Camp former director \#2 } \\
\text { Government liaison officer, NGO-C } \\
\text { Head of media relations, NGO-D* } \\
\text { Livelihood unit officer, UNHCR* } \\
\text { Logistics manager, NGO-B } \\
\text { Logistics officer, NGO-B } \\
\text { Policy officer, UNHCR } \\
\text { Program officer, NGO-A* } \\
\text { Relief Worker, NGO-D } \\
\text { Purchasing officer, UNHCR } \\
\text { Regional supply coordinator, UNHCR* } \\
\text { Retail supervisor, WFP } \\
\text { Store manager, Safeway** } \\
\text { Supply chain coordinator, WFP } \\
\text { Supply chain officer, UNHCR }\end{array}$ & $\begin{array}{l}\text { Za'atari refugee camp, 35, Arabic } \\
\text { Za'atari refugee camp, 40, Arabic } \\
\text { Za'atari refugee camp, 40, Arabic } \\
\text { Amman, 90, English } \\
\text { Amman, 70, Arabic } \\
\text { Za'atari refugee camp, 35, Arabic } \\
\text { Amman, 45, English } \\
\text { Teleconference call, 100, English } \\
\text { Amman, 45, Arabic } \\
\text { Amman, 60, English } \\
\text { Amman, 35, Arabic } \\
\text { Amman, 35, Arabic } \\
\text { Za'atari refugee camp, 35, Arabic } \\
\text { Amman, 45, Arabic } \\
\text { Za'atari refugee camp, 35, Arabic } \\
\text { Amman, 45, Arabic } \\
\text { Amman, 65, Arabic } \\
\text { Amman, 55, English } \\
\text { Za'atari refugee camp, 35, Arabic } \\
\text { Za'atari refugee camp, 40, Arabic } \\
\text { Amman, 35, English } \\
\text { Za'atari refugee camp, 65, English }\end{array}$ \\
\hline Refugee & $\begin{array}{l}\text { Community leader \#1 } \\
\text { Community leader } \# 2 \\
\text { Dairy products seller } \\
\text { Unemployed refugee } \\
\text { Elderly Bedouin refugees (wife* and husband) } \\
\text { Legal wholesaler employee } \\
\text { Farmer living in a Bedouin district. } \\
\text { Grocery retailer } \\
\text { Grocery wholesaler and retailer } \\
\text { Temporary worker at community center, NGO-A } \\
\text { Bedouin refugee } \\
\text { Mobile phone shop owner } \\
\text { Perfume shop owner } \\
\text { Restaurant owner } \\
\text { Street sweeper } \\
\text { University student refugee } \\
\text { Community center teacher (former lawyer in Syria)* } \\
\text { Teenage hairdressing assistant }\end{array}$ & $\begin{array}{l}\text { Za'atari refugee camp, 35, Arabic } \\
\text { Za'atari refugee camp, 35, Arabic } \\
\text { Za'atari refugee camp, 40, Arabic } \\
\text { Za'atari refugee camp, 35, Arabic } \\
\text { Za'atari refugee camp, 40, Arabic } \\
\text { Za'atari refugee camp, 35, Arabic } \\
\text { Za'atari refugee camp, 35, Arabic } \\
\text { Za'atari refugee camp, 45, Arabic } \\
\text { Za'atari refugee camp, 40, Arabic } \\
\text { Za'atari refugee camp, 35, Arabic } \\
\text { Za'atari refugee camp, 35, Arabic } \\
\text { Za'atari refugee camp, 35, Arabic } \\
\text { Za'atari refugee camp, 50, Arabic } \\
\text { Za'atari refugee camp, 30, Arabic } \\
\text { Za'atari refugee camp, 45, Arabic } \\
\text { Za'atari refugee camp, 75, Arabic } \\
\text { Za'atari refugee camp, 30, Arabic } \\
\text { Za'atari refugee camp, 40, Arabic }\end{array}$ \\
\hline
\end{tabular}

*Female interviewee. ${ }^{* *}$ Safeway is one of two WFP grocery contractors operating in the camp. 
Archival data was collected from policy papers, reports, other documents from the Jordanian government and NGOs/IGOs, documentary films, and social media related to the camp. These data revealed the history of the camp from the perspective of the media, as well as the social and cultural details of the refugees. Archival data also provided the triangulation of information collected during the interviews. Using the Lexis-Nexis database, the author team collected all local and international news articles about the camp from July 2012 to July 2016, as well as refugee challenges in the European Union (EU) and the region of Dara'a, home to more than $80 \%$ of the Syrian refugees in the Za'atari refugee camp. News reports and other media provided facts, testimonies, and first-hand stories of the refugees and camp operations. These data were valuable in providing earlier information on the camp, prior to the primary data collected by the author team. Social media (i.e., Facebook pages and YouTube videos) created by the refugees offered further insights into news stories and primary data from the camp.

\subsection{Data analysis}

Data analysis followed an iterative process. The initial coding was done in parallel with data collection (Glaser \& Strauss, 1967) and followed established guidelines offered by Gioia and colleagues (Gioia, Corley, \& Hamilton, 2013; Villena \& Gioia, 2018), Glaser \& Strauss (1967), and Miles and Huberman (1994). Members of the author team independently coded the interview transcripts collected by the lead author, and divergences were discussed until agreement was reached among the team members.

First-order coding captured the activities in the camp and provided a contextual understanding of how the various actor categories interacted with each other. These dataproviding information on flows of materials and allowing extensive mapping of actor activities 
and relationships-helped construct three supply networks that captured the critical economic activities of the refugees. Three stylized depictions (i.e., Figures 2, 3, and 4) were created for the three networks, with nodes representing the various actor groups. Separate, descriptive coding defined the relationships between the nodes, mapping where and how different transactions took place throughout the history of the camp. This analysis revealed where transactions occurred, such as inside or across the camp boundary, and in what direction (i.e., either formal or informal transactions between nodes). The nature of transactions between refugees who occupied more than one role (i.e., as informal retailers and buyers), both in the camp and in the host community, were sometimes curious and not always simple or, even, obvious. For example, some transactions required intermediaries or witnesses, while others allowed more flexible terms of payment. As a result, data from various archival sources and follow-up communications with camp-related actors were collected to reveal how economic and social activities in the camp were connected to actors beyond the camp boundary (i.e., actors involved in the formal and informal economies of the Mafraq host community).

Three key insights from the first order and descriptive coding helped uncover the qualitative character of the relationships between actors (i.e., nodes) during specific transactions. First, social ties — created prior to the conflict—sometimes existed between refugees and merchants or intermediaries within Mafraq. Since tribal connections with Mafraq allowed some of these refugees to assume specific intermediary roles, these refugees had access to resources (i.e., through family ties) that others did not have, finding unique transaction opportunities in the process. Second, governance for specific transactions was unique depending on the kind of goods being exchanged. Third, representatives of the camp authority (i.e., security guards) 
routinely tolerated trafficking. In some instances, security guards were complicit with refugees who — in the early days of the camp — transported and sold disassembled caravans across the camp boundary at night. Recognizing these unique aspects was highly valuable when interpreting our data. It not only led to a more critical assessment of the emergency-oriented, formal relief operations but also compelled a refugee point of view. As a result, our analysis accounts for the views of both refugees and outsiders (e.g., relief organizations).

Second order coding captured analytical themes, which were discussed among the members of the author team to ascertain the constructs animating the theory. This process led to the identification of three informal supply networks, as well as the social and economic constructs that shaped them. These informal supply networks were realized through constructs of refugee social capital that were associated with relational links, informal transaction governance, and transaction legitimacy. Together, these concepts drove and accentuated distinct features of the informal supply networks. Figure 1 summarizes the data structure. 


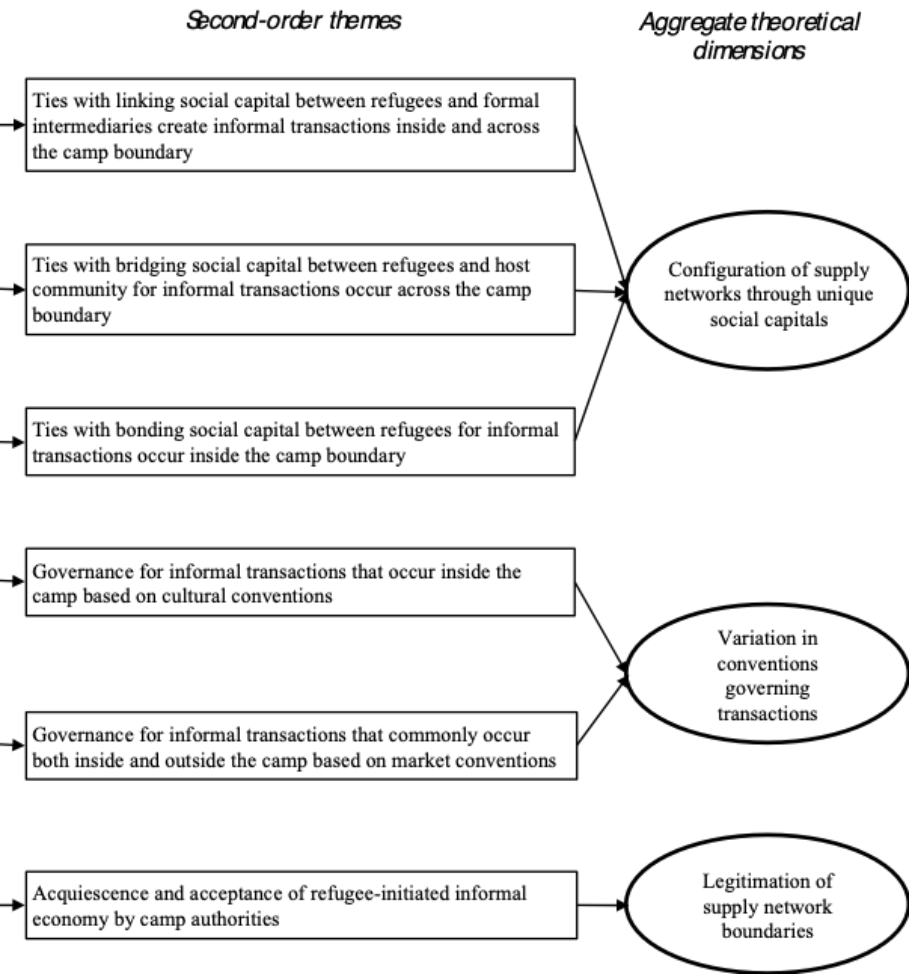

Figure 1. Data Structure of First-order Codes, Second-order Themes, and Aggregate Theoretical Dimensions.

Table 2 provides illustrative data and proof quotations that inform the data structure

presented in Figure 1 (see Appendix B for a reference list of the interviewees quoted in the study).

Table 2

Illustrative data and proof quotations.

Theoretical Dimensions, Second-order Themes, and Illustrative Data First-order Categories

\section{Configuration of supply networks through unique social capitals}

Ties with linking social capital between refugees and formal intermediaries create informal transactions inside and across the camp boundary

A. Designated community leaders are given exclusive control of distributing housing donations.
"There are community leaders for each street or area. The responsibility of these leaders is to help the UNHCR and NGOs distribute donations to the camp residents." (Child Protection Officer \#1, NGO-B, 2016) 
B. Designated community leaderspositioned between donation supply and recipient access in the campengage in unlawful distribution.

C. Designated community leaders informally and unlawfully sell caravans to refugees for profit.
"Community leaders do things like, for example, there was a donation of 3000 blankets to be distributed in the camp, but they stole most of them and each one has taken around 15 caravans and they sold us these donations later on." (Temporary Worker at Community Center, NGO-A, Refugee, 2017)

"Some refugees got more than one caravan for his family. So, they decide to sell the other caravan. Some of them would sell it because they need to afford the living expenses. Also, it happened that some of them leave the camp because they go back home or if they get a bailout guarantee to live outside the camp. Some of them migrated to Europe or other parts of the world, so they sell the caravans they used to live in." (Camp Site Supervisor, NGO-C, 2017)

Ties with bridging social capital between refugees and host community for informal transactions occur across the camp boundary

D. Refugees assume trafficking role to sell goods outside the camp boundary (regular and irregular transaction frequencies).

E. Refugees assume trafficking role in transactions for prohibited outside goods.

F. Tribal/family relationships aid informal transactions between refugees and the host community.
"In 2013, the refugees used to take some of the care packages and sell them in Mafraq stores [...] and buy other things that they needed, so now there is money generating in the camp and in the same time Syrian women started making food and started selling them to the employees and staff of NGOs." (Supply Chain Officer, UNHCR, 2016)

"Some people brought some sheep during the Adha Eid to slaughter them on the first day of Eid and there were some people selling sheep here. There are donkeys, but they are usually for carrying and transporting goods [...]; we smuggled them from the other end of the camp. A donkey would be sold for 200 Jordanian Dinars in the camp these days [...]. By the way, there are donkeys who are born in the camp now. So, they are traded in the camp." (Bedouin Refugee, 2017)

"Some of them were happy making the money inside of the camp and started trading and the famous Shams Élysées started to evolve. With the money people made, they were able to make deals with the local traders of the city of Mafraq, outside the camp — with whom some of them they had already business relations anyway from even before the crisis. So, the startup money quite often came from traders from the city of Mafraq. Even the plots for the 'Shams Élysées' were provided by the traders in Mafraq. Even licenses were given by families in Mafraq." (Camp Former Director \#1, IGO, 2017)

Ties with bonding social capital between refugees for informal transactions occur inside the camp boundary

G. Refugees encourage family and friends to engage in informal retail pursuits.

H. Refugees sell informally to other refugees through informal retailers in their local districts.
"I used to work in plumbing and now I have a dairy shop [in the market street]. Once one of my friends who owns a restaurant asked me if I could bring chicken drumsticks and I got 15 kilograms of them and they were sold within 3 minutes." (Dairy Products Seller, Refugee, 2016)

"I sell all of the credit I get from WFP, which is 160 Jordanian Dinars, to one retailer here in the Shams Élysées Street. He gives 120 Dinars for this. Some people sell their food shopping to these retailers at a cheaper price as well." (Temporary Worker at Community Center, NGO-A, Refugee, 2017) 
I. Informal small retailers with ties to informal large retailers - affiliated with host community wholesalersget preferential buying terms.
"My shop is here in the 'Sham Elysées' street. It is located around 10 minutes' walk from this retail store, so I walk every day or two to this store to have coffee with Mr. [name of informal wholesaler] and buy the products I need for my really small shop. [Then,] I can pay later after I sell my stock." (Grocery Retailer, Refugee, 2016)

\section{Variation in conventions governing transactions}

Governance for informal transactions that occur inside the camp based on cultural conventions

J. Approval to initiate informal selling determined through family connections.

K. Refugee transactions for selling businesses do not require formal contracts.

L. Families enlist as witnesses and maintain ownership knowledge for infrequent housing transactions.
"My parents pushed me to open this shop and then they started pushing me to get married. In a way they wanted to make me feel stable and to help me stop thinking about going back to Syria [...] No. I did not have previous experiences in repairing and selling mobile phones [...] but my cousins in Za'atari opened mobile shops before me and it was quite a successful business for them, so they encouraged me to open a mobile phone shop [...] I opened it next to my cousins' mobile shops." (University Student, Refugee, 2017)

"There are no contracts in the market inside the camp. There were cases in which misunderstandings happen between traders, and then we intervene to solve such disputes [...] The context [selling informally] is illegal but [how they are conducting] transactions are legal, so we have to intervene if a dispute happens." (Camp Court Lawyer, Government, 2016)

"There was no contract proving that he became my partner in the shop, and there are no official witnesses, but my family and his family know that he is a part owner in the shop and he became a partner in general, but they do not know the details." (University Student, Refugee, 2017)

Governance for informal transactions that commonly occur both inside and outside the camp based on market conventions

M. Refugee transactions for perishable products acquired through formal channels in the camp.

N. Refugee transactions for packaging materials acquired through formal permissions in the camp.

O. Refugees buy from informal retailers in the camp.

P. Refugees receive donations from the NGO/IGO network and sell conventionally.
"They [formal wholesalers] are not allowed to sell meat. They sell snacks usually but not meat. They do not have fridges and or any good storage conditions such as the ones in Safeway. So, they cannot have meat in stock. We can get most of the items. But for meats including chicken and lamb we get them from Safeway from inside the camp." (Restaurant Owner, Refugee, 2016)

"We get [all packaging and disposable meal containers] from outside the camp. Again, we need to have the names of the items written on a letter and send it to the camp management and get a permission to enter the materials." (Restaurant Owner, Refugee, 2016)

"Refugees in Azraq Camp [in Jordan] are forced to go to the shopping malls [WFP Supermarkets] to buy their goods, which is very expensive, but, here [at the Za'atari refugee camp], we have more options in the market to buy from." (Perfume Shop Owner, Refugee, 2016)

"Bikes from some donors were also distributed at some point and some of them [refugees] got more than necessary and then they sold them. Bikes are a major business in Mafraq now as it is widely used in the city of Mafraq and the camp as well." (Supermarket Cashier, Host Community, 2018) 
Acquiescence and acceptance of refugee-initiated informal economy by camp authorities

Q. Camp authorities aware of regular informal transactions.

R. Lax monitoring of informal retailing practices by camp authorities.
S. Varied enforcement of penalties by camp authorities once goods are inside camp.
"There are not contracts between the owners of the caravans and the users of the caravans $[\ldots]$. We don't intervene in organizing the market. We intervene if there is a complaint by others. Although this is illegal [selling and renting caravans], as long as there are no complaints, or this is not making troubles for others we don't intervene." (Community Police Officer \#2, Government, 2016)

"It is quite easy to open a shop by refugees in the camp because they do not need to do any licensing. As long as they do not tease or annoy others then they are free to open a small business. They do not need to get permission from any legal entity to open a business there. They use sheds and wood and such things. Sometimes they would pack their business stuff and go back home, and they open again in the next day." (Relief Worker, NGO-D, 2016)

"They [donkeys and sheep] are allowed but we cannot bring them through the camp's main gate. It is not allowed to bring them legally, but once we have them inside the camp, it is ok." (Bedouin Refugee, 2017)

The trustworthiness and validity of this study was assessed through credibility, transferability, dependability, confirmability, and integrity (Flint, Woodruff, \& Gardial, 2002; Hirschman, 1986; Lincoln \& Guba, 1985). Following Strauss and Corbin (1990), the criteria of fit, understanding, generality, and control common to grounded studies were examined. Table 3 demonstrates that our data and analyses met these criteria.

\section{Table 3}

Trustworthiness of study and findings: Interpretative and grounded theory criteria.

Trustworthiness Criteria

Credibility: extent to which results appear to be an acceptable representation of these data.

\section{Method of Addressing Trustworthiness in this Study}

Prolonged, four-year engagement in field environment with multiple data sources.

- Work presented for external feedback at three peer-reviewed organization management/management conferences, one refugee-specific symposium, and three university seminars.

Result: revised theoretical model benefited from feedback.

Transferability: extent to which findings from one study in one context apply to other contexts.
Theoretical sampling used to choose unique refugee camp.

Result: conceptual model was evaluated against published reports on other camps to ensure that key constructs were relevant across settings. 
Dependability: extent to which findings are unique to time and place, and explanations are stable or consistent.

Confirmability: extent to which interpretations are the result of participants and phenomenon as opposed to researcher biases.

Integrity: extent to which interpretations are influenced by misinformation from, or evasions by, participants.
- $\quad$ Facts and interpretation of events triangulated by other interviewees and data sources (e.g., archival data, media reports, newly published research dissertations, recent papers, and documentaries).

Result: events were consistently interpreted.
- $\quad$ Author team involved in independent coding and data analysis.

- Data analysis procedures described and recorded.

- In-depth discussions with academics and practitioners with expertise in migration, informality, and supply networks helped clarify perplexing data.

Result: coding and interpretation were refined.
- Data triangulation accomplished through interviews with multiple participants and comparison with facts reported in news and recent dissertation.

- Interviews conducted professionally with sensitivity to interview participants.

- $\quad$ Author team followed ethical guidelines for working with vulnerable populations.

Result: no obvious bias from interviewees or attempts to mislead the author team; author team was sensitive to cultural nuances during interviews, fieldwork, data interpretation, and writing, to avoid objectifying refugees.

Fit: extent to which findings fit with substantive areas under investigation.

- Methods addressed credibility, dependability, and confirmability.

Result: concepts were richly described and extended; concepts provided a convincing characterization of supply networks.

Understanding: extent to which participants accept results as possible representation of their worlds.

- $\quad$ Research results presented to two NGO personnel working in refugee camps and to an audience of migration scholars and practitioners.

- $\quad$ Reflexivity incorporated in methodology; author team discussed observations and insights with refugees for feedback and comments.

- $\quad$ Peer-debriefing through presentations to scholars working in operations management and organizational theory at three conferences and three seminars.

Result: colleagues and researchers were brought into findings.

Generality: extent to which findings reveal multiple aspects of the phenomenon.
- Multiple sources of data and background data were collected and analyzed.

- Interviewees include all key actor groups.

Result: multiple aspects and competing perspectives of the phenomenon were captured.
Control: extent to which organizations influence aspects of the theory.
- Individuals from various actor groups could influence variables in proposed theory.

Result: refugees were able to influence relationships and transactions within the network; NGOs/ IGOs and host government had a strong impact on the amount and allocation of relief support, which in turn influenced functioning of supply networks. 


\section{History of the Za'atari refugee camp}

In response to a large influx of refugees at the onset of the Syrian Civil War, the Za'atari refugee camp was established in the summer of 2012. At six kilometers from the Syrian border and 10 kilometers from Mafraq (i.e., the host city of the camp), the Jordanian government allotted three square miles of desert land to support Syrian refugees fleeing both sides of the conflict. Most of the refugees arriving in Jordan were from two rural regions in mid-southern Syria—some from Dara'a (97\%) and the remaining from Homs, rural Damascus, and Hama. Dara'a is a natural extension of northern Jordan, and both Dara'a and Mafraq are located on the Hauran plain, where Syrians share similar cultural norms, ethnic mores, and a largely Sunni Muslim religious background with most Jordanians (Hourani, 1991). A deep history of social relations - in areas now occupied by Syrians and Jordanians - predates the establishment of national borders and has been sustained through intermarriages and cross-border trade relations (Hourani, 1991). For example, within the Za'atari refugee camp, there is a strong presence of refugees with ties to the Al-Hariri family — an influential, patriarchal family whose ties extend beyond the camp and whose leadership is based in Irbid, Jordan. Refugee connections with Jordanian families, such as the Al-Hariri family, mark life in societies where clan-affiliation can open access to resources, networks, reputation benefits, and labor or economic opportunities.

A good portion of the refugees from border regions had made a living in border trade. In one interview, a UNHCR leader referred to these refugees as "traders and smugglers" prior to the Syrian Civil War. For many, the camp was an opportunity to access and trade goods, as demonstrated by some earlier, opportunistic refugees who were designated "community leaders." Historically, seven large family clans have been widely recognized across Syria and Jordan 
(Hourani, 1991). In many instances, clan affiliations provided a starting point for Syrian refugees, as they could be housed by Jordanian relatives living in Mafraq. However, those refugees from families of less means most often lived in the camp and received some form of support from relatives living in Mafraq. Family relationships between the refugees and the people of Mafraq also created economic linkages. The large family clans of Mafraq became prominent wholesalers who offered loans and financial support to their relatives so that they could start their own businesses.

Since the establishment of the camp in 2012, the Syrian Refugee Camps Directorate (SRCD) has represented the Jordanian government in the management of security at the camp. Daily operations were first managed by the local NGO, the Jordan Hashemite Charity Organization for Relief and Development (JHCO), which later turned over this responsibility to the UNHCR in 2013. Since then, the UNHCR has managed more than 20 critical local and international NGOs (e.g., Mercy Corps, the Norwegian Refugee Council, the Agency for Technical Cooperation and Development, OXFAM, and Save the Children) in the implementation of its program in the camp.

Since the standard humanitarian relief approach of the UNHCR focused on formal, sustenance-based relief operations, this left various unmet expectations or predilections for many of the refugees. Low-quality, prepackaged meals, shared bathrooms and communal kitchens, and supply shortages were problematic. Shortages were created by the corrupt activities of looselydesignated community leaders tasked with roles of relief supply distribution. In the first 12 to 15 months of the camp, refugees rejected some standards of relief care that was being provided by 
all camp authorities (i.e., the Jordanian government and IGOs/NGOs). ${ }^{3}$ Refugees commonly leveraged a powerful agency, rejecting relief operation structures provided by the various organizations. Resistance led to protests and demonstrations against relief efforts and spontaneous challenges to the program of the UNHCR. A sizeable and outspoken contingency of refugees - having immigrated from a mid-income economy_-believed that the camp relief supplies were inadequate, especially when comparing them to what they were accustomed to back home. Their dissatisfaction was further aggravated by a lack of economic opportunities. Amid the chaos of a rapid influx of refugees, the cultural expectations and-perhaps most importantly — the sense of desperation and lack of trust for fellow refugees led to ongoing and often violent protests.

Such a context prompted the refugees to engage in informal trading and exchanges that led to vibrant camp marketplaces. These marketplaces quickly received attention from the media and Western governments who touted the camp as a "success story" against the backdrop of the unfolding refugee crisis in Europe. By the end of the data collection period in 2018, the Za'atari refugee camp had grown to include twelve districts and a stable population of around 80,000 - $\mathrm{a}$ significant drop from its peak of over 200,000 in April of 2013. Between 2012 and 2018, more than 460,000 refugees passed through the camp and were registered with the UNHCR. In 2013 , it cost $\$ 500,000$ (USD) to operate the camp, with refugees consuming 4.2 million liters of water per day and creating electricity costs of $\$ 750,000$ (USD) per month (The New Humanitarian,

\footnotetext{
${ }^{3}$ In some instances, we discovered that Syrian refugees were comparing themselves to Iraqi refugees who had taken up residence in Syria at the onset of the First Gulf War. In their view, the Iraqi refugees had received better accommodations than what the Syrians had received in Jordan.
} 
2013). In the Za'atari camp, the population had an equal gender split, with $76 \%$ of the women responsible for childcare and home-related duties.

Since the beginning of the Syrian Civil War in 2011 to 2019, Jordan received about 1.5 million Syrian refugees. Hosting Syrian refugees had mixed implications for the Jordanian government, including long-term stability in the region, external aid received from EU countries, and pressures placed on housing, education, healthcare, and infrastructure. Concerns of refugees taxing Jordanian infrastructure and competing in the labor market were particularly high in the economically depressed region of Mafraq, which was largely oriented towards agriculture (REACH, 2014). Such concerns made the Jordanian government wary of development-oriented donations and relief work from IGOs and NGOs.

\section{Findings}

Perhaps the most daunting challenge faced by the refugees was finding relative stability and reconstructing their lives inside the camp. Refugees began this process by engaging in improvised, secondhand transactions, buying and selling donated relief goods among themselves and with Mafraq residents. Relief goods were also repurposed as new production materials. Acting in concert, refugees — with some actors from the formal relief organizations — adopted roles of buyers, suppliers, distributors, wholesalers, retailers, traffickers, and service providers. The formal and informal economic activities of all actors gave shape to the supply networks in the camp.

Our analyses uncovered three theoretical dimensions, which delineated the transactionsand their functioning - within three informal supply networks: (a) the positioning of social capital; (b) the governance of transactions according to culturally- and market-guided 
conventions; and (c) the legitimation of informal transactions. The first dimension—drawn from working definitions of social capital in the disaster science literature-addressed ties within the supply networks. While bonding social capital accounted for ties that were more familiar, such as family members, close friends, or neighbors (Woolcock, 2002), bridging social capital connected actors to resources in parallel networks, such as other neighborhoods, clans, and social groups (Putnam, 2000). Finally, linking social capital captured ties that were characterized by differences in power distance, social status, or hierarchy (Szreter \& Woolcock, 2004).

In section 5.1, we describe how transactions supported the three informal supply networks: (a) building materials and housing; (b) electricity and electrical hardware (henceforth, "electricity"); and (c) food and goods. We also highlight the network-specific relevance of the theoretical themes with respect to the informal supply networks. In section 5.2, we describe the three theoretical dimensions.

\subsection{Three informal supply networks}

We focused on building materials and housing, electricity, and food and goods for three reasons. First, products and services associated with the three informal supply networks were critical in meeting the basic needs of refugees and therefore had practical implications for the daily lives of refugees. Second, formal relief operations and refugee-initiated informal operations interacted to support the flow of resources in these networks. Finally, these networks were representative of economic activities involving refugees. ${ }^{4}$

In Figures 2, 3, and 4, the structures of the three informal supply networks are provided

\footnotetext{
${ }^{4}$ These networks differed from healthcare-related supply networks, which were fully controlled by IGOs/NGOs. Networks for water supply and sanitary services, which bore similarities to the network for electricity and electrical hardware, were omitted in this study for brevity and scope reasons.
} 
as stylized depictions, which identify key actor groups (i.e., nodes with three icon shapes), specific actor roles (i.e., descriptive texts), the relative size of actor groups (i.e., three icon sizes), the direction of material flows within transactions (i.e., arrow direction), and whether transactions were considered formal or informal (i.e., blue denotes formal, and red denotes informal). ${ }^{5}$ Concentric circles represent nodes of actor groups that occupy more than one role (i.e., an informal buyer and seller). Blue-colored nodes of actor groups and material flows are associated with formal operations in relief distribution or formal transactions within a network. These include not only NGOs/IGOs but also local wholesalers and retailers who sell items directly to the refugees, their informal small retail shops, and informal wholesalers in the camp. Red-colored nodes of actor groups and material flows are associated with informal transactions. 5.1.1 The building materials and housing supply network

As depicted in Figure 2, the building materials and housing supply network was essential for constructing the physical buildings at the camp. Together, these structures (i.e., the marketplace and residential shelters) represented the built environment at the camp. When incoming refugees arrived at the camp, they were given a tent from the UNHCR (i.e., obtained through their expansive donation networks); however, housing-related donations shifted from tents to caravans as the first winter approached. Caravans were prefabricated metal structures with a hard floor occupying 16 square meters. During the early days of the camp, responsibilities for distributing housing and building materials—including caravans and metal sheets for room partitioning—were given to specific refugees who self-identified themselves as "community

\footnotetext{
5 The stylized depictions present a variety of nodes rather than an actual number of nodes in the network. While they demonstrate how supply chain transactions are supported by relational structural characteristics, they do not provide a systematic evaluation of the sociometric attributes of the network (e.g., centrality and network density).
} 
leaders" to camp authorities. According to UNHCR personnel, these designated community leaders were hastily recruited since it was assumed that they were respected by other refugees. Further, recruitment was largely based on English-speaking skills, as noted by one IGO personnel:

They are not real community leaders; they are people who come to you and happen to speak English, so you like them already because they speak English as foreigners. (Camp Former Director \#2, IGO, 2017)

Even though they were difficult to monitor and evaluate by relief personnel, designated community leaders had unique access to relief workers and, thus, the distribution of housing resources. They engaged in the formal distribution of some of the resources following the expectations of their role; however, they also informally gave or sold some of the resources following family or kinship ties. According to one refugee:

They [the designated community leaders] started helping the relief organizations by distributing meals. After that, they became known for [distribution on behalf of] these organizations and they helped them by distributing caravans where they benefit from this through getting more for themselves and their relatives. (Temporary Worker at Community Center, NGO-A, Refugee, 2017)

By taking this step, designated community leaders created a market based on secondhand transactions for housing and building-related materials. Some caravans-regardless of whether they were acquired formally or informally—were disassembled and, through coordination with other refugees, trafficked outside the camp by refugees who had connections with informal buyers in the host community. For example, flatbed carts were created out of caravan pieces obtained inside the camp and used car tires sourced from outside the camp. Large structures were also transported by rolling them on felled electricity poles. 
If housing structures were sold in the camp - whether they were used as a shop or a family dwelling, these transactions required some form of oversight. Here, governance was supported by community elders or neighbors who enlisted as witnesses to the transaction. These types of transactions were described by one refugee who had sold a caravan that had been originally converted into a shop:

So, I sold it [the caravan] out and opened a small restaurant. Then, I sold it to the shop owner next to me. There were no contracts or official witnesses. There are no contracts in the camp [...], no official witness but traders in the market know that the shop was sold to someone else. We do not need official witnesses. (Restaurant Owner, Refugee, 2016)

Inside the camp, buying and selling a caravan followed cultural conventions of honor and reputation, where an important transaction that was done in bad faith could result in that individual being socially sanctioned or isolated. However, if a caravan was sold through an intermediary to a buyer in the host community in Mafraq, this transaction was governed by market conventions and required no witnesses.

In sum, the building materials and housing supply network was born out of illegal activities that were initially pursued by the designated community leaders. On one hand, transactions that followed family or kinship ties leveraged bonding social capital inside the camp. To support these transactions, cultural conventions were deployed to curtail opportunistic behavior and disputes. On the other, transactions that extended network boundaries outside the camp were associated with bridging social capital. 


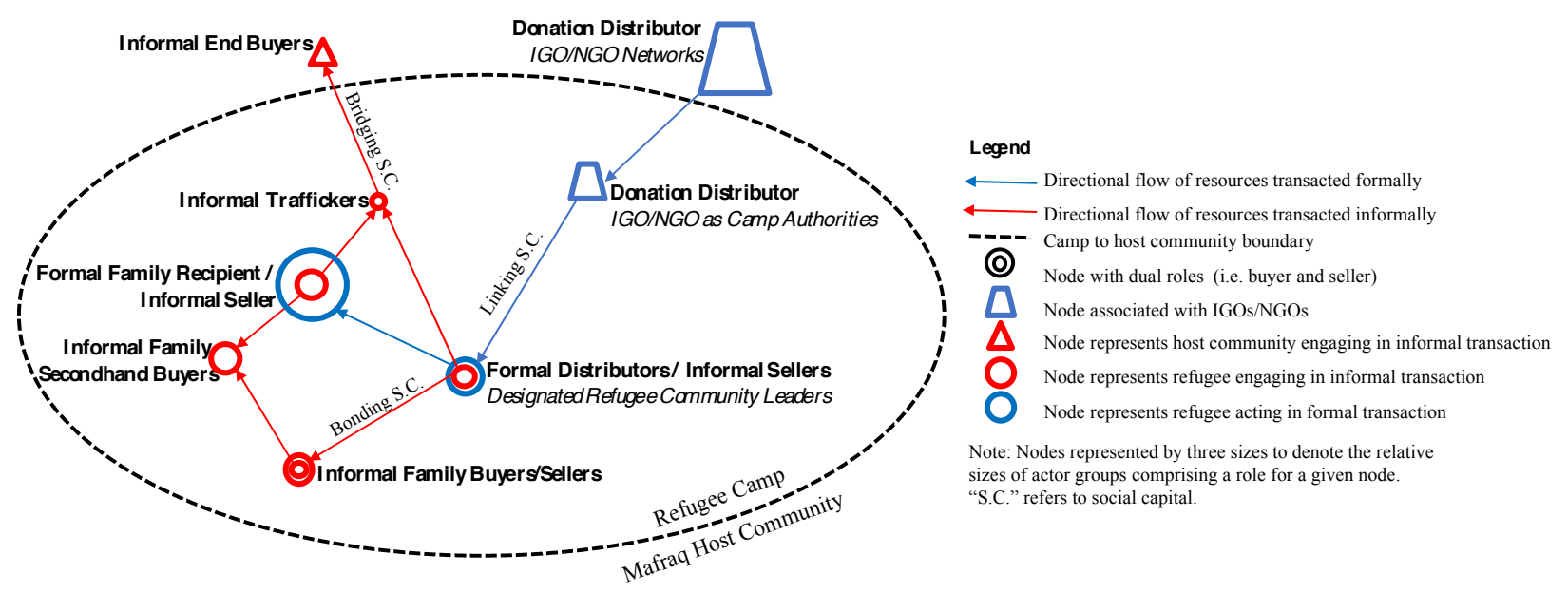

Figure 2. The Building Materials and Housing Supply Network

\subsubsection{The electricity supply network}

Figure 3 depicts the electricity supply network. In the planning of the camp, camp

authorities sourced electricity from a local utility company to provide power for communal paths (i.e., streetlights) and shared facilities (e.g., community spaces, shared kitchens, and bathrooms), as well as for the facilities of IGO/NGOs and the Jordanian government (e.g., offices, police stations, and clinics). The original design of the camp granted refugees formal access to the electrical grid through shared communal areas. However, once durable housing structures were in place, an electricity supply network emerged: refugees began siphoning electricity to power their houses and shops. Refugees with electrical skills engaged in brokerage transactions to provide access to electricity through a market-guided, one-time fee-for-service model. Buyers of such services included families and retailers. Several refugees and camp managers mentioned that hostilities of refugees for camp authorities quickly abated once refugees started to power up their caravans in late 2013:

People were organizing the theft of electricity. There were 350 electricians working in the camp to implement this and connect electricity to shops and 
houses. I was asked every day to cut electricity because the bills UNHCR was paying for stolen electricity were over 500,000 dollars a month, but I said 'no' because electricity is light; electricity is business, electricity is safety and so on. (Camp Former Director \#1, IGO, 2017)

Beyond access to electricity through improvised and informal interfaces with the formal supply of electricity to community spaces, individual families inside the camp also required specific hardware, such as wiring, panels, and switches. Electrical hardware was trafficked by some refugees across the camp boundary by leveraging bridging social capital in informal transactions with retailers outside the camp.

The electricity supply network was the most streamlined of the three informal supply networks, both in terms of the number of actor groups involved and the simplified nature of the transactions. In the camp, the dyadic transactions of this network occurred according to a marketguided convention of a one-time fee-for-service model. Transactions did not require strict monitoring or oversight. Compared to sales of caravans between families, power connection services were governed by prearranged prices rather than through personal relationships with electricians. Access to electricity was thus governed by market conventions of standardized pricing and fairness.

Finally, the interface between the informal (i.e., depicted in red in Figure 3) and formal (i.e., depicted in blue in Figure 3) portions of the network indicates that informal service providers were critical brokers for access to electricity. This interface - and the network ties that were created — was made possible by camp authorities (i.e., the UNHCR and the Jordanian Government) who acquiesced and accepted the network established by the refugees. The lack of 
law enforcement afforded illegal wiring activities a measure of legitimacy, and were, therefore, justified in the eyes of traffickers and refugee customers.

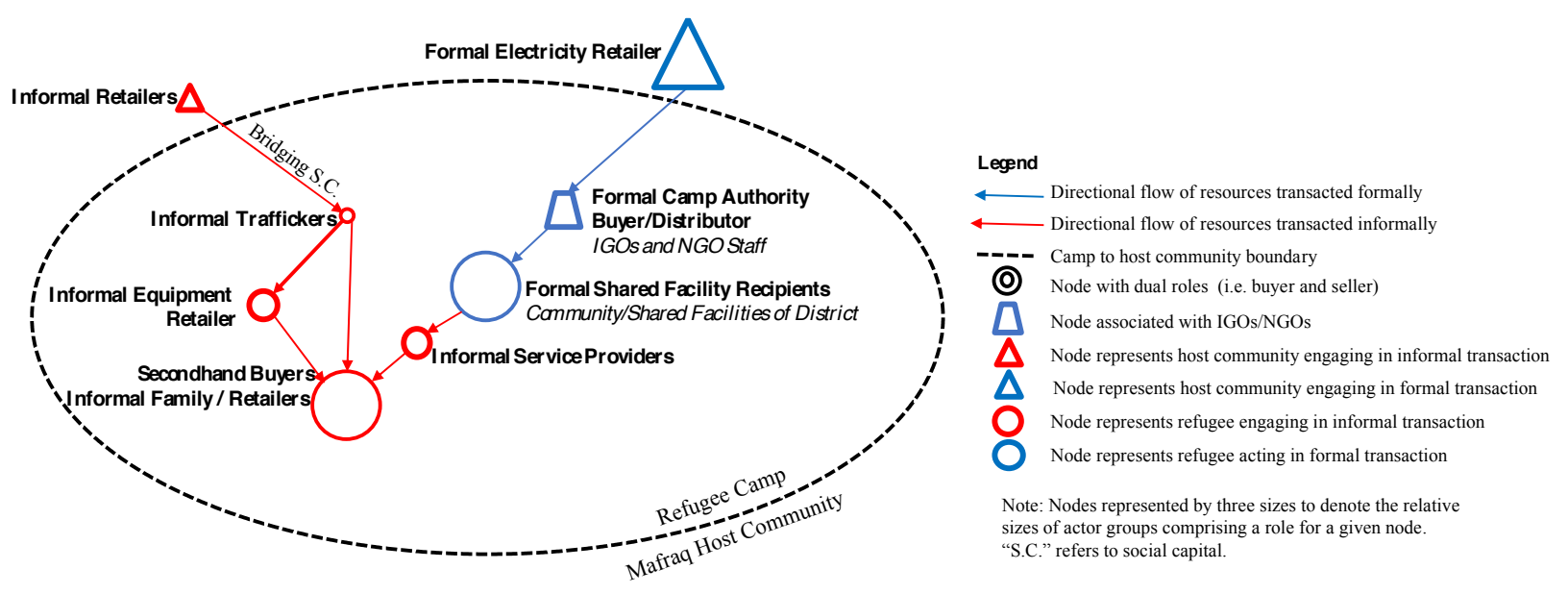

Figure 3. The Electricity Supply Network

\subsubsection{The food and goods supply network}

The third and most elaborate informal supply network, food and goods, is depicted in

Figure 4. Food included both packaged and perishable food items, while goods accounted for a variety of basic goods (e.g., phones and SIM cards, appliances, and clothing), lifestyle goods (e.g., wedding gown rentals), and rural goods to support sustenance or economic opportunities (e.g., goats and service donkeys) that were routinely utilized by Bedouin refugees. Inside the camp, these goods were sourced from relief donations. From the beginning, the WFP was contracted by the UNHCR to provide pre-packaged meal kits. Dissatisfied refugees protested the poor quality and often flawed distribution of food rations. In early 2014, the WFP contracted Safeway and Tazweed (i.e., the Jordanian national grocer) to open shops inside the camp. The WFP issued vouchers so that the refugees had more opportunities to purchase what they needed, such as specific ingredients and frozen raw meats to cook traditional meals. 
Informal transactions of food and goods originated from the resale of donated goods, as well as exchanges that occurred between formal and informal retailers and commercial wholesalers in Mafraq. Over time, practical needs and informal market opportunities motivated further refugee-to-refugee and refugee-to-host community transactions. By engaging in barter and trade transactions, these actor groups sustained and expanded the network. The government acknowledged the positive economic spillover in Mafraq and eventually approved the relaxing of border crossing policies by camp authorities. Informal, small retailers now received permits from camp security officers to bring in goods through formal means, and merchants from Mafraq were allowed to bring in goods as wholesalers. Thus, many formerly illicit economic activities accomplished through trafficking were now considered legitimate. However, trafficking illicit goods into the camp was not without risks; lawbreakers, if prosecuted, could be sent back to Syria. An indication of the resilience of this network was its continued growth in size and sophistication over time. Its success culminated in the creation of vibrant marketplaces in different camp districts, which motivated camp authorities and the host government to continue to ease their policies on informal buying and selling practices.

Bonding and bridging social capitals, which supported specific kinds of transactions in the camp and across the camp boundary, contributed to the resilience of this supply network. Bonding social capital supported informal, small retailers present in local marketplaces, and buying and selling involved economic and social engagement with families residing in a district. Continued interactions between informal, small retailers and informal, large retailers led to bonding ties (e.g., a smaller retailer buying merchandise on credit). As noted by one informal, small retailer: 
I cannot [as a small retail shop in the marketplace] buy from the same wholesale supplier who supplies this large retailer because I cannot buy in large quantities and, also, I cannot always pay in cash, but this retailer is one of my acquaintances from back home and he gives me products on credit. (Grocery Retailer, Refugee, 2016)

Bridging social capital supported the flow of goods entering the camp by extending the boundaries of the supply network beyond the camp. Conventional food and goods were brought into the camp through 14 camp-sanctioned formal wholesalers. Bridging social capital—between refugees who could claim a connection with Mafraq-based clans and the wholesalers connected to those clans - was instrumental in facilitating informal access to such goods. Bridging social capital also facilitated access to goods that were either discouraged or prohibited by camp authorities. These transactions required traffickers to act as intermediaries between refugees-or informal small retailers - and their connections in the host community. The deftness of traffickers in overcoming security challenges for a variety of goods was evident. For example, some refugees originating from a Bedouin ethnic group had been able to acquire live animals:

I know a guy who works as a street sweeper $[\ldots]$. [H]e is renting out his donkey to the retailers in the market street to carry goods from the wholesaler warehouses. There is a good use of donkeys here-especially for those who cannot afford to establish new shops in the market. (Bedouin Refugee, 2017)

While bridging social capital helped determine the intermediaries in the network, the actual transactions were governed by a more straightforward one-time fee-for-service/product model. Thus, a market-guided convention—one not only free of culturally-guided obligations (e.g., presence of witnesses) but also bringing cultural familiarity of Syrian market life to the Jordanian camp — regulated tactical buying and selling activities. In such instances, transactions occurred with regularity, predictability, and efficiency. 


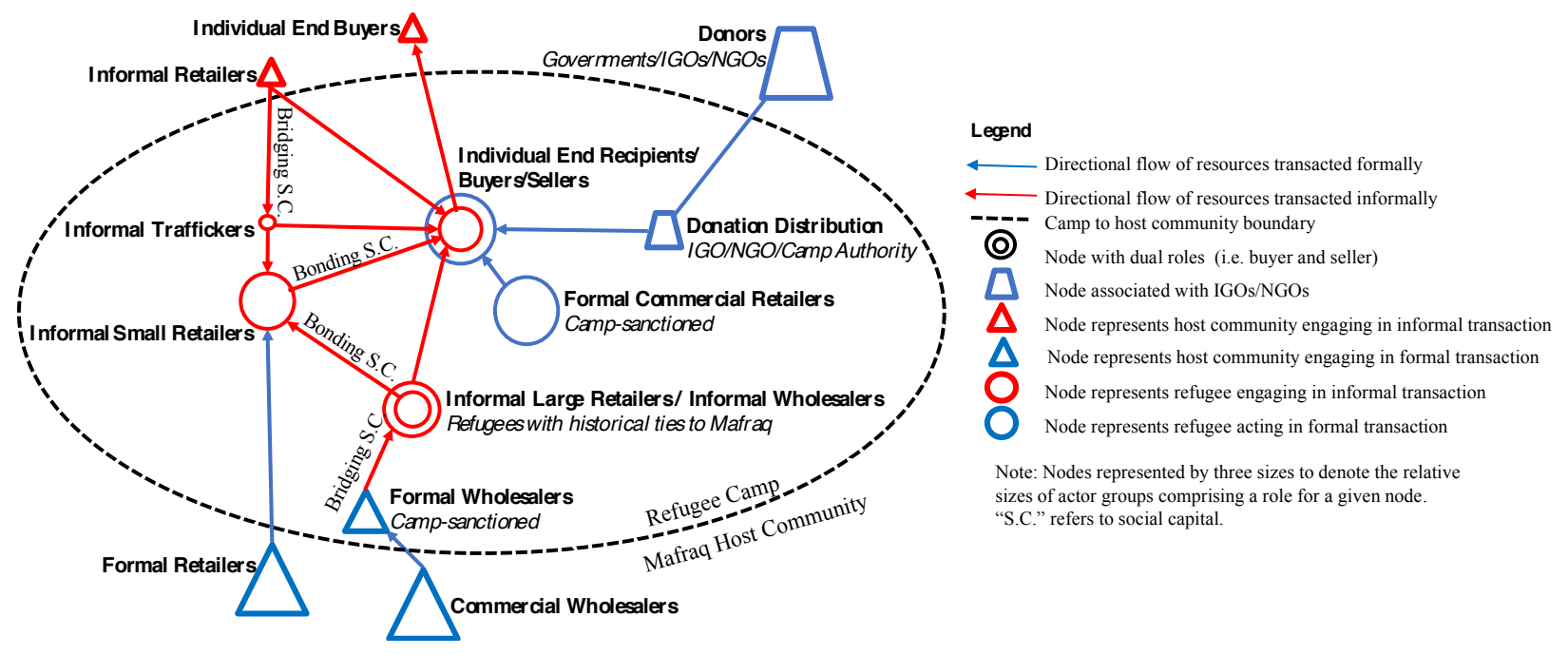

Figure 4. The Food and Goods Supply Network

5.2 Key dimensions of refugee-initiated, informal supply networks

In this section, we describe the three theoretical dimensions, which delineate the transactions and their functioning in the three informal supply networks: (a) legitimation of refugee-initiated economic activities; (b) positioning of unique social capitals; and (c) governance of transactions according to specific conventions.

\subsubsection{Legitimation of refugee-initiated economic activities}

Refugee-initiated transactions constituted the informal economy and exchange relationships in the three informal supply networks. The associated economic activities were either illegal (e.g., trafficking) or sanctioned (e.g., setting up storefronts), amidst lax enforcement of camp rules. Interviews with UNHCR officials and locals in Mafraq revealed that many of the camp security guards were hired locally. These guards felt that the citizens of Mafraq also deserved access to relief supplies; goods coming from outside the region were resources that could support the whole area, including impoverished locals hosting refugees in Mafraq. In this 
context, the cultural obligation of service to family/clan interests had economic consequences and defined the interests and decision-making of security guards employed from the host community. Guards also favored the interests of refugees and locals over law enforcement, since they often came from standards of living that were at or below the level of some refugees. This stance translated into a more permeable or flexible camp border in terms of the kinds of goods that could cross the camp boundary. As a result, guards, as representatives of the camp authority, did not consistently stop the trafficking of goods across the camp border and allowed informal supply networks, as well as the traffickers inside and across the camp boundary, to be legitimated.

The Jordanian government was aware of the level of informality in the camp but recognized that strict monitoring and law enforcement had economic repercussions for the host community. Over time, the government legitimated this informality by allowing businesses in Mafraq to sell directly to informal retailers and wholesalers in the camp. Such policies not only led to more goods and people flowing between the camp and the host city but also the proliferation of the informal supply networks. As noted by one government official, informal markets were acknowledged and allowed:

The way this market was formed is because some refugees felt in the beginning that they get in-kind donations such as detergents, food items and extra blankets from WFP and other NGOS, and they wanted to sell these extra in-kind donations and get cash for it. So, they used to sell them outside the camp. Then, they started to exchange it with other refugees in inside the camp. Then they opened small random booths to sell these in-kind donations for the newcomers into the camp. It was random. So, we could not prohibit them. [But], it is not a proper [formal] market. (Government Official \#1, Ministry of Interior, 2016) 
Refugees were also aware of leniency, as noted by one refugee who had become a university student in Jordan:

Buying and selling caravans is obviously not allowed but no one checks on this. The NGOs and camp management [UNHCR] know about this definitely, but they do not care. I do not know why but [it] may be because they do not want to put pressure on people inside the camp. I do not know. (University Student, Refugee, 2017)

Similarly, UNHCR camp authorities acquiesced and accepted a level of illegal activities to reduce conflict in the camp. UNHCR camp authorities avoided restricting illegal transactions and allowed relief supplies to be used for inputs in the informal supply networks. By accepting these illegal and informal activities, the UNHCR supported the continuity and the adaptability of the three informal supply networks. The UNHCR also recognized that such refugee activities improved the living conditions in the camp, which further legitimated the illegal economic activities. Overall, the government and camp authorities recognized that informality helped sustain the livelihoods of the refugees and bring positive economic opportunities to the host community. Table 4 presents the activities of refugees and the humanitarian relief operations of camp authorities that led to the development and legitimation of informality occurring within the supply networks. 


\section{Table 4}

Refugee activities leading to the development of informal supply networks and humanitarian relief operations leading to the legitimation of informal supply networks.

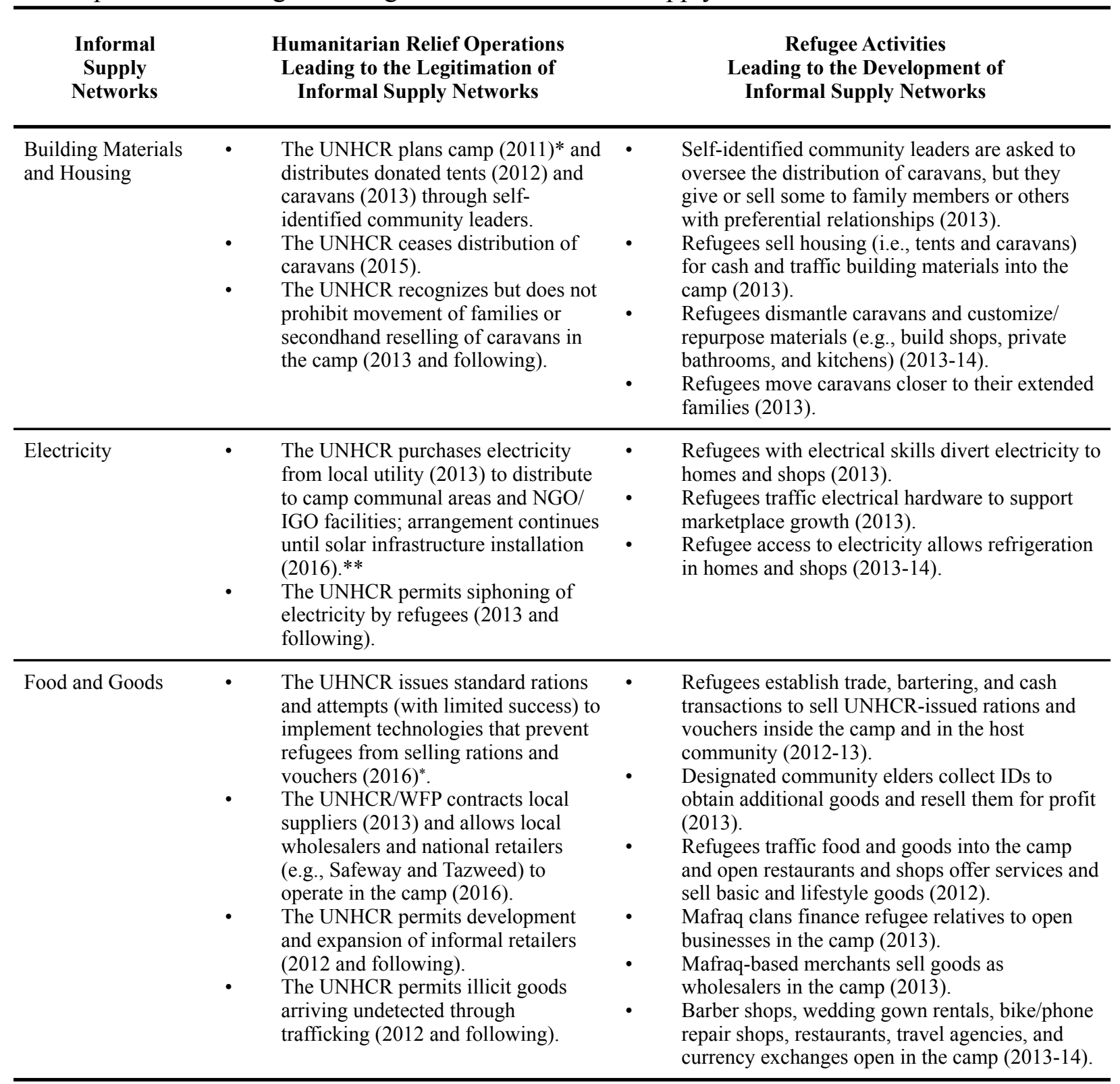

*Year specifies the time when operations began or when operations were prevalent.

**https://data2.unhcr.org/en/documents/download/67947

\subsubsection{Positioning of unique social capitals}

The relational ties that refugees established inside and outside the camp were a salient

feature in each of the three informal supply networks. Bonding, bridging, and linking social

capitals both enriched the dyadic transactions between nodes of actor groups and configured the 
informal supply networks. Thus, these three forms of social capital endowed camp refugees with opportunities for economic exchange and access to restricted resources. Table 5 presents the three forms of social capital conceptualized in disaster science research and represented in the three informal supply networks of the Za'atari refugee camp (Aldrich, 2011; Holguín-Veras et al., 2012a; Putnam, 2000; Schuller, Baron, \& Field, 2000; Szreter \& Woolcock, 2004; Woolcock, 2002).

\section{Table 5}

Conceptualization of social capital in disaster science research and representation in informal supply networks.

\begin{tabular}{|c|c|c|}
\hline $\begin{array}{c}\text { Forms of } \\
\text { Social Capital }\end{array}$ & $\begin{array}{c}\text { Conceptualization in } \\
\text { Disaster Science Research }\end{array}$ & $\begin{array}{c}\text { Representation in } \\
\text { Informal Supply Networks }\end{array}$ \\
\hline Bonding & $\begin{array}{l}\text { Connecting individuals bonded by } \\
\text { family, kinship, or geospatial } \\
\text { proximity. } \\
\text { Commonly existing in the same } \\
\text { affiliations, networks, social groups, or } \\
\text { organizations. }\end{array}$ & $\begin{array}{l}\text { - Accounts for designated community leaders giving or } \\
\text { selling caravans to family members or others with } \\
\text { preferential relationships (e.g., the building materials } \\
\text { and housing supply network). } \\
\text { Accounts for informal relationships between refugees } \\
\text { and informal camp retailers, and between informal } \\
\text { small retailers and informal wholesalers (e.g., food } \\
\text { and goods supply network). }\end{array}$ \\
\hline Bridging & $\begin{array}{l}\text { Connecting individuals of similar status } \\
\text { with other distinct social groups (e.g., } \\
\text { groups that have access to different } \\
\text { resources). } \\
\text { Commonly existing in unique } \\
\text { affiliations, networks, or organizations. }\end{array}$ & $\begin{array}{l}\text { Accounts for mainly informal transactions between } \\
\text { actors outside the camp and intermediaries/traffickers } \\
\text { inside the camp (e.g., all three supply networks). } \\
\text { Accounts for infrequent transactions of informal } \\
\text { wholesalers with camp-sanctioned wholesalers (e.g., } \\
\text { food and goods supply network). } \\
\text { Accounts for frequent transactions of informal } \\
\text { wholesalers with camp-sanctioned, formal wholesalers } \\
\text { (e.g., food and goods, and electricity supply } \\
\text { networks). }\end{array}$ \\
\hline Linking & $\begin{array}{l}\text { Connecting individuals of unequal } \\
\text { status with other distinct social groups } \\
\text { (e.g., groups that have access to } \\
\text { different resources). } \\
\text { Commonly existing in unique } \\
\text { affiliations, networks, or organizations. }\end{array}$ & $\begin{array}{l}\text { Accounts for the actions of actors at the interface between } \\
\text { formal actor (e.g., UNHCR) and informal actor transactions } \\
\text { (e.g., designated community leaders within the building } \\
\text { matemials and housing supply networtk). }\end{array}$ \\
\hline
\end{tabular}

Bonding social capital was used by the designated community leaders when they

deliberately misallocated caravans to family members or others with preferential relationships.

These transactions led to the creation of an informal supply network in building materials and 
housing. When interacting with camp authorities in such transactions, linking social capital was also used by intermediaries (i.e., traffickers) to gain unique and exclusive access to outside resources donated to the camp. Thus, designated community leaders helped configure the building materials and housing supply network as they interfaced between the formality of donation distribution (i.e., receipt of resources from outside the camp) and the informal and unlawful distribution of donated housing to unintended recipients inside the camp and in the host community. Bonding social capital was also mobilized among refugees and informal retailers in the marketplaces of each camp district, as well as between informal small retailers and informal wholesalers who had a history of acquaintance in the camp. All these actors were instrumental in configuring the food and goods supply network.

Bridging social capital was the only form of social capital found across all three informal supply networks, with transactions based on historical affiliations with cross-country border clans in Mafraq. Except for selling caravans outside the camp, the intermediaries (i.e., traffickers) leveraged ties to obtain resources that could only be bought beyond the boundaries of the camp. Here, bridging social capital was used by informal, large wholesalers—who also operated as informal retailers in the camp — to gain special access to camp-sanctioned, formal wholesalers in the food and goods supply network. These transactions (e.g., to procure live animals or contraband concrete mix), were discreet and less frequent. However, bridging social capital was frequently used by traffickers who were not only the sole outgoing supply channel for buyers outside the camp in the building materials and housing supply network but also the sole incoming supply channel to marketplaces in the electricity supply network (e.g., for electrical hardware). 
In sum, the three forms of social capital not only defined the boundaries of the informal supply networks in the camp but also expanded their boundaries beyond the borders of the camp. Bonding, bridging, and linking social capital were used by actors to constitute the three informal supply networks, enabling efficient economic exchanges and cultivating trusting relationships. By expanding network boundaries and creating richer relationships, the resilience of these supply networks was supported.

\subsubsection{Governance of transactions according to specific conventions}

Network governance is a set of mechanisms used to monitor and control the behavior of one entity or a group of entities to protect the interests of members associated with a network. In this study, the three supply networks of the informal economy were all linked to the formal relief network. The formal relief network was largely governed by explicit rules and policies and managed through a hierarchy. The Jordanian government entrusted camp management to the UNHCR, which in turn, coordinated the formal relief operations of other IGOs/NGOs that worked with either donated or appropriated funds. In contrast, the three informal supply networks were self-organized. Unlike supply networks in a peacetime context, there was neither a single network administrator or buyer group coordinating network members nor explicit contracts or rules governing transactions (Choi \& Hong, 2002; Grandori \& Soda, 1995; Pathak, Wu, \& Johnson, 2014; Pilbeam, Alvarez \& Wilson, 2012; Provan \& Kennis, 2008). We found that different types of transactions in the supply networks were governed by either culturally- or market-guided conventions (Biggart \& Beamish, 2003). Table 6 summarizes these conventions governing transactions at the Za' atari refugee camp. 
Table 6

Conventions governing transactions.

\begin{tabular}{llll}
\hline $\begin{array}{l}\text { Transaction } \\
\text { Conventions }\end{array}$ & \multicolumn{1}{c}{ Conceptualization } & \multicolumn{1}{c}{ Representation in Supply Networks } \\
\hline $\begin{array}{l}\text { Culturally- } \\
\text { guided }\end{array}$ & - & $\begin{array}{l}\text { Transactions occur through barter, trade, or } \\
\text { partial trade/cash exchange. } \\
\text { Governance is achieved through witnesses and } \\
\text { mutual acquaintances to ensure fairness. } \\
\text { Witnesses enlisted as contract surrogates and } \\
\text { monitoring mechanisms (i.e., social sanctions } \\
\text { and reputational penalties occur when deals go } \\
\text { awry). }\end{array}$ & $\begin{array}{l}\text { Efficiency realized in less common transactions } \\
\text { and higher value exchanges inside the camp (e.g., } \\
\text { informal buying and selling caravans in the } \\
\text { secondhand market of the building materials and } \\
\text { housing supply network). } \\
\text { Predictability built into transactions due to the } \\
\text { consequences of getting caught by camp } \\
\text { authorities (e.g., camp ejection for both } \\
\text { individuals). }\end{array}$ \\
\hline $\begin{array}{l}\text { Market- } \\
\text { guided }\end{array}$ & $\begin{array}{l}\text { Transactions occur through a predetermined or } \\
\text { fixed fee-for-service/product. } \\
\text { Governance is achieved without monitoring } \\
\text { mechanisms. } \\
\text { Relational components of buying locally create } \\
\text { a social familiarity between buyers and sellers, } \\
\text { which sustains ongoing economic exchange. }\end{array}$ & $\begin{array}{l}\text { Efficiency realized in more common transactions } \\
\text { and lower value exchanges both inside and } \\
\text { outside the camp (e.g., informal buying and } \\
\text { selling of electrical hardware and lifestyle goods } \\
\text { in the electricity and food and goods supply } \\
\text { networks). } \\
\text { Predictability based on a high frequency of } \\
\text { exchange between the same individuals. }\end{array}$ \\
\hline
\end{tabular}

The exchange relationships in the electricity supply network were the least complex of the three. Refugees with electricity skills controlled the access to and distribution of electricity services, with residents and shop owners paying market prices for access. Business relationships between informal service providers (i.e., suppliers) and refugees (i.e., buyers) were based on a one-time fee-for-service model. Once a transaction was complete, the dyadic tie became dormant. While new electricity service demands were eventually met in the camp, such marketguided conventions still served aftermarket needs, such as electrical hardware and repairs.

The building materials and housing supply network was governed by a combination of clan-based exchange norms and market conventions. Designated community leaders prioritized the distribution of caravans to family members and others with preferential relationships (e.g., kinship ties). At the same time, caravans and building materials were also sold through a profitdriven underground market agnostic to who bought the caravans. When a family was able to leave the camp, they sold the caravan at market price. Since selling caravans was considered 
illegal, refugees respected exchange norms to keep transactions fair and transparent, as well as to avoid alerting camp authorities to transaction disputes or complications. In essence, this cultural convention managed transaction risk since social sanctions or even clan ostracization could occur if a deal went awry. Thus, designated community leaders and traffickers had disproportionate level of power and influence in the flow of resources through the building materials and housing supply network. For example, one refugee - after leaving the camp for an unusually long period of time - asked a designated community leader for his old caravan upon his return. While the request was not granted, the victim was not willing to report his grievances to camp authorities:

Well... the [designated] community leaders do things like... if you went outside of the camp in an illegal way they would sell your caravan to someone and once you are back you cannot complain about this because it was illegal to be out of the camp. (Unemployed Refugee, 2016)

Compared with the other two networks, the food and goods supply network operated according to market-guided conventions and required less oversight. A greater variety of goods were more frequently bought and sold, which suggested a denser network with a higher number of interacting nodes. The market was sustained by transactions and a continuous flow of materials, which became a crucial part of the economic and social activities of the refugees. Further, this network was more complex because family and clan-based relationships overlapped business relationships. However, the informal transactions between buyers and sellers in the camp, as well as those between refugees and members of the host community, were largely governed by market conventions that were culturally understood in such settings. These transactions mirrored those found in Syrian markets; buyers made purchases in their own districts, and transactions were conducted with interpersonal warmth and familiarity that resulted 
in frequent and repetitive interactions. With these social features, transactions followed a marketguided, one-time fee-for-service/product model, where the incentive to keep transactions fair and reasonable came from social incentives for continuity through repeat transactions (Biggart \& Beamish, 2003).

\section{Theorizing informal supply networks}

The three informal supply networks emerged and expanded in response to changes in the supply and demand of resources in the camp. When the demand for certain products and services, such as housing and electricity stabilized, supporting network structures and boundaries remained but became dormant in response. However, when the demand other products, such as food — and especially goods — increased, the corresponding supply network expanded and increased in complexity to meet the demands of the broader network. By concentrating on three informal supply networks, this case study presents a narrative of network resilience amid changes within and across the camp boundary, which informs our core research question: how do the economic activities of refugees shape humanitarian relief operations inside a refugee camp? Employing a set of constructs that relate to informality, tie characteristics, network governance, and network resilience, we present a theory of informal supply networks.

In this case, the three informal supply networks account for many dyadic and often spontaneous exchanges that supported a flourishing marketplace. Each network was governed by self-organized actors rather than by a single lead buyer or independent entity. Further, cultural understandings guided how—and if—coordination mechanisms were required to govern transactions (Pathak et al., 2014). For high-value transactions (e.g., building materials and 
housing), witnesses were enlisted, and for common commerce activities, market-guided conventions were used as part of a one-time fee-for-service/product model (Biggart \& Beamish, 2003). The intermediaries — or boundary spanners — resided in a communication position found either between the informal supply networks and formal relief operations or between the camp and the host community. As articulated by Geertz (1978, p. 31), the advantages they possessed as a pivotal broker in this setting "stems from surrounding oneself with relatively superior communication links" or difficult-to-access resources. Thus, intermediaries functioned as brokers and exploited arbitrage opportunities afforded by their network positions.

While buyers, sellers, and intermediaries all sought profit and/or arbitrage opportunities, they also selected partners for economic exchange (Khoury \& Prasad, 2016) by following cultural norms of family and kinship, leveraging both bonding and bridging forms of social capital. Wholesaler-retailer dyads often had exclusive relationships based on previous social ties. The prioritization of family and kinship relationships in Syrian society also influenced the characteristics of the informal supply networks (e.g., key players and exchange relationships). Thus, a market-guided convention for common transactions was embedded within broader social networks of trusted exchange partners connected by bonding social capital. The informal supply networks accommodated exchange relationships that infused both culturally- and market-guided conventions to guide the selection of exchange partners and transactions.

The informal operations of the three supply networks were also inextricably connected to formal relief operations through linking social capital, as the formal operations of the IGOs/ NGOs and the camp authorities interfaced with the self-organized, informal operations of the refugees. The intermediaries (i.e., traffickers) served as a nexus through which formal relief 
resources and economic transactions within the host community were converted and channeled into informal transactions. Some informal operations of the supply networks eventually became an extension of formal relief operations and expanded the broad relief network to include regional suppliers outside the camp boundary. Camp authorities also legitimated the informal marketplaces and the development of informal supply networks by their acquiescence and acceptance of informal activities. Had the camp authorities been able — or willing - to deter these transactions, the informal operations of the supply networks originating in the camp would not have prevailed, and their positive economic impact - for both refugees and the host community —would not likely have occurred.

Whereas humanitarian relief operations fulfilled the basic survival needs of the refugees, refugee-initiated economic activities — carried out through the informal supply networks_supplied goods and services that supported the quality of life in the camp. These economic activities addressed taken-for-granted human development needs, such as having familiar homecooked meals, private bathrooms and lighting, partitioned spaces for family members, and proximate relatives. The informal operations of these supply networks met these needs not only by providing infrastructure for material flows but also by creating the physical space necessary for social interactions and economic exchanges. As more refugees participated in the informal supply networks as buyers, sellers, and intermediaries, more relational ties were formed. This led to increased tie density_ particularly, in the growing food and goods supply network. Economic transactions were infused with social ties and interactions informed by interconnections between linking and bonding social capital. The development of relational complexity in the informal 
supply networks also marked the development of social relationships among refugees in the camp.

The resilience of these supply networks was crucial to serving and sustaining the economic and human development needs of the refugees. Our analysis points to stability and adaptability dimensions of resilience. As important performance indicators (Dooley, 1997; Holling, 1996; Novak, Wu, \& Dooley, 2021), stability reflects the capability of a network to retain a robust form, and adaptability reflects the capability to evolve and accommodate a wide breadth of exchange relationships. In the context of a refugee camp, informal supply networks should not only sustain basic and taken-for-granted development needs but also adapt to changing refugee needs, shifting camp policies, and fluctuating levels of relief resources from IGOs/NGOs. Therefore, resilience implies that informal supply networks can develop and allow new channels to emerge and develop both inside and outside the camp.

By considering nodal characteristics, relational ties between actor groups, and underlying social guides, we define informal supply networks as an aggregate of predominantly illicit-yet legitimate-channels and social relationships, governed by culturally-and market-guided conventions that support the economic exchange of goods and services between distinct actors or actor groups.

In Figure 5, we propose a model that delineates the essential elements of an informal supply network and specifies the theoretical relationships between the constructs. 


\section{Informal Supply Network Configuration}

- Exchange ties formed by varied forms of social capital (bonding, bridging, and linking)

- Governance of transactions guided by cultural and market conventions

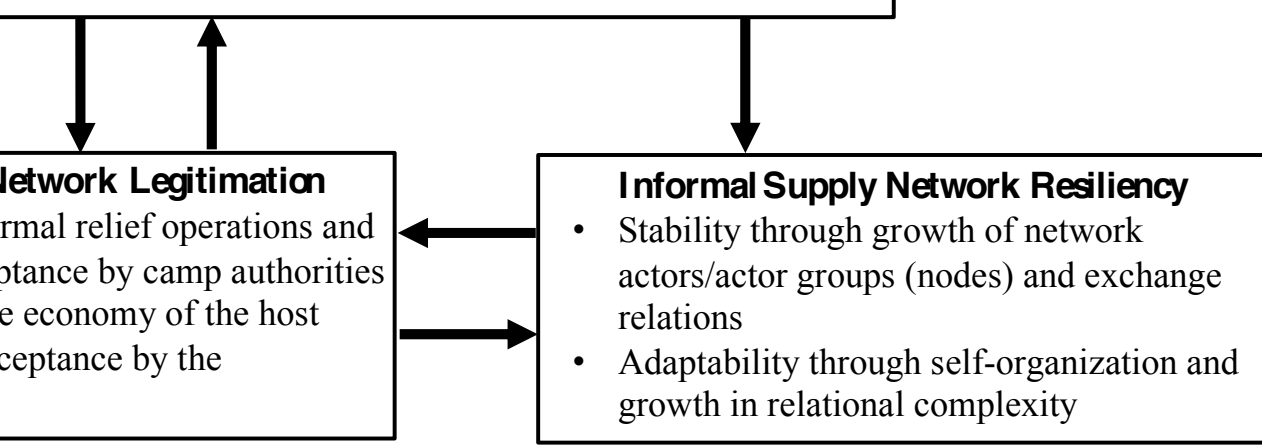

Figure 5. Conceptual Model of an Informal Supply Network.

An informal supply network is configured through robust relational ties based on varied types of social capital (i.e., bonding, bridging, and linking) and governance of transactions by culturally- and market-guided conventions that open flows of relief resources from different entities within the network. Legitimation occurs through the integration of an informal supply network with formal relief operations both inside and outside the refugee camp, and with the economic activities of the host community. In both cases, integration is made possible through acquiescence and acceptance by camp authorities and by government. In turn, a legitimized informal supply network nurtures social capital and institutionalizes the governance of exchange.

Rich ties—infused with social capital—support network resilience by stabilizing the informal supply network and enhancing its ability to adapt to changes in the environment. The development of transaction conventions and social capitals also reinforces network legitimation, which in turn enhances network resilience. Integration of informal supply networks with formal relief operations, and with the economy of the host community, will generate a positive 
economic impact both inside the camp and in the host community. This leads to a positive feedback loop between network legitimation and network resilience.

\section{Discussion}

Our case study makes three important theoretical contributions. First, we propose a theory of informal supply networks. Contributing to what Provan, Fish, \& Sydow (2007, p. 509) call "a lack of studies on the effectiveness of networks", we delineate the key constructs that underlie a resilient structure of informal transactions and how they shape the boundaries of a network. This study uses the context of a refugee camp to define the operational characteristics of informal supply networks and to reveal how these networks are able to self-organize, serve specific functions, and interact with formal relief operations and the host community. This study also highlights the vital roles of intermediaries who interface formal operations and expand the boundaries of informal supply networks. With linking and bridging social capitals, intermediaries initiate and structure the informal supply networks, connecting informal and formal networks both inside and outside the camp.

Second, as one of the first exploratory studies of informal supply networks in a refugeecamp setting, this study contributes to studies in disaster science and humanitarian relief operations (Holguín-Veras et al., 2012, a,b; Quarantelli, 2005). This study also broadens the scope of considerations for supply networks in operations management research by examining supply networks in an emergency-oriented context (Hällgren, Rouleau, \& de Rond, 2018). By examining this extreme context, we uncover the social behaviors of refugees and the social characteristics that underlie tie formation and network structuring. These findings emphasize the significance of investigating the social behaviors of all actors engaged in emergency-oriented 
contexts and the management of humanitarian relief operations, and thus address calls for a better understanding of development in humanitarian relief operations (Gupta et al., 2016; Pedraza-Martinez \& Wassenhove, 2016; Sanyal, 2012; Starr \& Van Wassenhove, 2014).

Finally, this study contributes to the literature that addresses informal economies (Fadahunsi \& Rosa, 2002; Williams \& Shahid, 2016). While recent contributions have focused on the character of institutions as a determinant of the extent of informal enterprise within a locality (Webb et al., 2020), this study extends current research both empirically and theoretically by capturing the complex and nuanced interactions of a variety of actors in informal economic pursuits, as well as of the intermediaries who link formal and informal supply networks. This study also reveals how the legitimacy of informality and the structuring of informal supply networks is achieved through different forms of social capital. We uncover how the actions of social guides — rooted in both culturally- and market-guided conventions (Biggart \& Beamish, 2003) — inform the exchange behaviors of refugees and lead to network resilience. This study offers an alternate perspective on the productive value of the informal economy for refugees who are not served by the state and its various contracted agents. By exposing the impact of creating and redirecting informal supply networks to overcome difficulties imposed by social and geospatial isolation, this study also contributes to our understanding of challenges to agency when attempting to improve the economic livelihoods of vulnerable populations (Khoury \& Prasad, 2016).

This case study offers four practical insights for refugee camp management. First, it dispels the notion of powerless and passive refugees; refugees are not victims awaiting charity. The refugee camp is a society, constituted by members from every social level. Refugees have 
both agency and development needs like individuals in peacetime societies, and they leverage social capital as a resource to rebuild a sense of cultural familiarity and normalcy as they endure their situations (Alloush et al., 2017). Humanitarian organizations, such as IGOs and NGOs, should recognize the unique power, resources, and social skills of refugees so that they can better support the needs of refugees and help channel the agency of refugees towards improved livelihoods.

Second, intermediaries are crucial in the development and functioning of an informal supply network. Understanding the roles of intermediaries can help demystify modern conceptualizations of the informal economy (Webb et al., 2020). In many cases, these roles represent an important entry point for the development-oriented relief work of IGO/NGOs and governments. Since relief organizations have the power to legitimize, they can influence the development trajectories of agentic refugees in the creation of informal supply networks. Further, development agencies and camp authorities should mentor and socialize intermediaries to help integrate informal supply networks with formal relief operations coordinated through IGOs and NGOs.

Third, the economy of refugees invariably interfaces with the economy of host community (Taylor et al., 2016). Thus, we encourage governments to view refugees as individuals capable of enriching their settings. Taking the view of Sendra and Sennett (2020) on the value of designing for disorder, it is rare for a community to find ways of developing new social networks across class and ethnic boundaries. The social and economic integration of a camp with a host community presents a worthy experiment of productive disorder that can lead to the development and economic empowerment of both refugee and host community 
populations. In this case study, Mafraq — an economically underdeveloped host community— found new opportunities by integrating the refugee population. However, these new opportunities emerged at a grassroots level, through bottom-up means between refugees and host community residents rather than through initiatives created by the local government. The presence of cultural symmetries between populations not only facilitated the creation of new opportunities but also diminished the liabilities of foreignness that could have hampered economic exchange. Thus, a host community should consider how cultural affinities (or lack thereof) impact the social and economic integration of refugees in the regional economy. Equally important, IGOs/NGO and government should consider the needs (e.g., infrastructure, and healthcare/education capacity) and capabilities of the host community when deciding how to allocate resources in a developing refugee camp economy. These actors can also remove social barriers and create incentives, such as the use of localized sourcing and supply chains to facilitate integration.

Finally, humanitarian relief operations should become more development-oriented in their approach to vulnerable populations. In this case study, the host community of Mafraq clearly benefitted from the socially- and economically-resilient refugee camp of Za'atari. Understandably, most host governments are unwilling to provide refugees anything beyond basic sustenance needs and IGOs/NGOs must work within the boundaries set by 1951 Refugee Convention. Further, humanitarian organizations and governments also recognize that informal economies operate in a grey area with questionable legality and are often directly connected with illegal underground economies where many actors are exploited without legal recourse. From the standpoint of the host government, a more transparent and formalized refugee economy would reduce exploitation and reduce public safety and security risks. Therefore, humanitarian 
organizations and governments should collaborate with informal supply networks and integrate them into the formal relief system.

This study has several limitations that can inform future research opportunities. The realization of the Za'atari refugee camp can be attributed to a host of factors, including the hospitality of the Jordanian government, the social capital of the refugees inside and outside the camp, the cultural affinities between Syrians and Jordanians, and the steady relief funding of the UHNCR and other NGOs/IGOs. Few other refugee populations around the world have had access to such social and economic resources following the forced mass displacement of a population. Many camps (e.g., the Lesbos-based camp in Greece) accommodate diverse ethnic groups, which would lead to different exchange relationships and network structures (Agier, 2011; Betts et al., 2017). Future studies should investigate diverse settings of informal supply networks to capture how new exchange norms form and how informal supply networks emerge. A deeper understanding of network resilience also accounts for adaptation, which requires longitudinal studies that can capture not only major and meaningful change but also the effects of change over time.

In this study, the success of the informal supply networks was related to the efficacy of the UHNCR and its development-oriented relief work. The operations of the UHNCR have been constrained by the 1951 Refugee Convention that mandated emergency-oriented relief missions. As such, the UHNCR has treaded lightly between providing sustenance and addressing economic and human development needs. This may point to the outdatedness of the Convention: it simply does not account for large-scale refugee migration from the global south to economicallydeveloped countries (Agier, 2011). The on-going refugee challenges in Europe and the unfolding 
crisis at the southern border of the U.S. call for a more humanistic reconceptualization of refugee resettlement — one that accounts for the human development needs of the refugees, the economic opportunities for host communities, and, at the same time, the resources necessary to accommodate a sudden population influx. These policy decisions will affect the operations of IGOs/NGOs, governments, and private sector participants. Future research should continue to explore different development-oriented strategies in refugee management, as well as the efficacy of new strategies to create new refugee and migration policies and to change existing, and largely failing, refugee management practices.

Finally, greater emphasis is being placed on the role of technology in humanitarian relief operations (Fisher, 2018). Cell phones and social media have been widely adopted by refugees in Za'atari as tools for communication with relatives in Syria, conducting business, and engaging donors. Future research should leverage data collected from information technology to investigate social structuring and supply network operations. However, researchers must be aware of the challenges of protecting the identities of vulnerable populations and the potential ethical questions associated with camp authorities implementing monitoring technologies (Jones, 2016).

In sum, our exploratory case study of the Za'atari refugee camp supports the assertion that human settlements should be allowed to develop organically over time, with individuals and communities granted the autonomy to freely define their own environment in the pursuit of success (Scott, 1998). We uncovered not only how refugees could build a vibrant economy but also how they could rebuild their society inside a refugee camp. We call upon scholars to study similar contexts - involving refugees and the potential agency of refugees - to discover better 
ways to channel humanitarian relief, thus helping refugees to regain their dignity and realize their potential under the circumstance of displacement.

\section{Conclusion}

While the stark challenges faced by Syrian refugees have elevated the plight of all refugees in the minds of politicians and citizens across the world, these challenges have also triggered a surge in nationalist movements and hardline policies on migration-related issuesfrom deterring economic migrants to halting the entry of asylum-seekers fleeing oppressive regimes and natural disasters (Jones, 2016). The crisis of effectively serving refugee populations is likely to remain an ongoing challenge, against a backdrop of global pandemics, climate catastrophes, and political extremism. At the heart of these issues are various policies for effectively managing national borders, such as locating humanitarian relief efforts closer to the home countries of the refugees. Our modern system of accounting for refugees-implemented after World War II—no longer functions adequately in an age of sudden human displacements and mass migrations. Unfortunately, policies are framed according to the view that hosting refugees is inherently problematic (Chowdhury, 2020), where modern discourses cast refugees as a challenge to domestic security, a threat to the demography of communities, and a drain on social services support.

The case study of the Za'atari refugee camp underscores the real challenges of hosting refugees. However, the Za'atari refugee camp — amidst its opportunities and obstacles—also differs from its predecessors, offering a new approach to managing mass migration. We contend that a development-based approach, which allows for flexible humanitarian relief policies and 
agentic refugees engaging in economic and social activities, offers a promising path forward. 


\section{REFERENCES}

Adger, N. W., Hughes, T. P., Folke, C., Carpenter, S. R., \& Rockstrom, J. (2005). Socialecological resilience to coastal disasters. Science, 309(5737), 1036-1039.

Agier, M. (2011). Managing the undesirables: Refugee camps and humanitarian government. Cambridge, UK; Malden, MA: Polity.

Aldrich, D. P. (2011). The externalities of strong social capital: Post-tsunami recovery in Southeast India. Journal of Civil Society, 7(1), 81-99.

Alloush, M., Taylor, J. E., Gupta, A., Valdes, R. I. R., \& Gonzalez-Estrada, E. (2017). Economic life in refugee camps. World Development, 95, 334-347.

Anderson, B. (2013). Us and them? The dangerous politics of immigration control. Oxford, UK: Oxford University Press.

Arar, R. (2017). Leveraging sovereignty: The case of Jordan and the international refugee regime. In Refugees and Migration Movements in the Middle East (pp. 12-15). Los Angeles, CA: University of South California.

Barnett, M. (2014). Refugees and humanitarianism. In E. Fiddian-Qasmiyeh, G. Loescher, K. Long, \& N. Sigona (Eds.), The Oxford Handbook of Refugee and Forced Migration Studies (pp. 241-252). Oxford, UK: Oxford University.

Berger, R. (2015). Now I see it, now I don't: Researcher's position and reflexivity in qualitative research. Qualitative Research, 15(2), 219-234.

Betts, A., Omata, N., \& Bloom, L. (2017). Thrive or survive? Explaining variation in economic outcomes for refugees. Journal of Migration and Human Security, 5(4), 716-743.

Biggart, N. W., \& Beamish, T. D. (2003). The economic sociology of conventions: Habit, custom, practice, and routine in market order. Annual Review of Sociology, 29(1), 443-464.

Browning, L. D., Beyer, J. M., \& Shetler, J. C. (1995). Building cooperation in a competitive industry: Sematech and the semiconductor industry. Academy of Management Journal, 38(1), 113-151.

Chatty, D. (2016). The Syrian humanitarian disaster: Disparity in perceptions, aspirations and behavior in Jordan, Lebanon and Turkey. IDS Bulletin, 47(3), 19-33.

Choi, T. Y., \& Hong, Y. (2002). Unveiling the structure of supply networks: Case studies in Honda, Acura, and Daimler Chrysler. Journal of Operations Management, 20(5), 469-493.

Chowdhury, R. (2020). The mobilization of noncooperative spaces: Reflections from Rohingya refugee camps. Journal of Management Studies. doi:10.1111/joms.12612

Collier, P., \& Betts, A. (2017a). Refuge: Rethinking refugee policy in a changing world. Oxford, UK: Oxford University Press.

Collier, P., \& Betts, A. (2017b). Why denying refugees the right to work is a catastrophic error. Retrieved from https://www.theguardian.com/world/2017/mar/22/why-denying-refugees-theright-to-work-is-a-catastrophic-error. Accessed on 18 November 2018. 
Dalal, A. (2014). Camp cities between planning and practice: Mapping the urbanisation of Zaatari Camp. Stuttgart University \& Ain Shams University.

Dalal, A. (2015). A socio-economic perspective on the urbanisation of Zaatari Camp in Jordan. Migration Letters, 12(3), 263-278.

De Montclos, M-A. P., \& Kagwanja, P. M. (2000). Refugee camps or cities? The socio-economic dynamics of the Dadaab and Kakuma Camps in Northern Kenya. Journal of Refugee Studies, 13(2), 205-222.

Dooley, K. J. (1997). A complex adaptive systems model of organization change. Nonlinear Dynamics, Psychology, and Life Sciences, 1(1), 69-97.

Drabek, T. E. (1986). Human system responses to disaster: An inventory of sociological findings. New York: Springer-Verlag.

Dunn, E. C. (2018). No path home: Humanitarian camps and the grief of displacement. Ithaca, NY: Cornell University Press.

Dynes, R. (2005). Community social capital as the primary basis of resilience. University of Delaware: Disaster Research Center, Preliminary Paper \#344.

Eisenhardt, K. M., \& Graebner M. E. (2007). Theory building from cases: Opportunities and challenges. Academy of Management Journal, 50(1), 25-32.

Eisenhardt, K. M. (1989). Building theories from case study research. Academy of Management Review, 14(4), 532-550.

Fadahunsi, A., \& Rosa, P. (2002). Entrepreneurship and illegality: Insights from the Nigerian cross-border trade. Journal of Business Venturing, 17(5), 397-429.

Fisher, K. E. (2018). Information worlds of refugees. In C. F. Maitland (Ed.), Digital lifeline? ICTs for refugees and displaced persons (pp. 79-112). Cambridge, MA: MIT Press.

Flint, D. J., Woodruff, R. B., \& Gardial, S. F. (2002). Exploring the customer desired value change phenomenon in a business-to-business context. Journal of Marketing, 66(4), 102-117.

Geertz, C. (1978). The bazaar economy: Information and search in peasant marketing. The American Economic Review, 68(2), 28-32.

Gioia, D. A., Corley, K. G., \& Hamilton, A. L. (2013). Seeking qualitative rigor in inductive research: Notes on the Gioia methodology. Organizational Research Methods, 16(1), 15-31.

Glaser, B. G., \& Strauss, A. L. (1967). The discovery of grounded theory: Strategies for qualitative research. Chicago, IL: Aldine.

Grandori, A., \& Soda, G. (1995). Inter-firm networks: Antecedents, mechanisms and forms. Organization Studies, 16(2), 183-214.

Gupta, S., Starr, M. K., Farahani, R. Z., \& Matinrad, N. (2016). Disaster management from a POM perspective: Mapping a new domain. Production and Operations Management, 25(10), 1611-1637. 
Hällgren, M., Rouleau, L., \& de Rond, M. (2018). A matter of life or death: How extreme context research matters for management and organization studies. Academy of Management Annals, 12(1), 111-153.

Hirschman, E. C. (1986). Humanistic inquiry in marketing research: Philosophy, method, and criteria. Journal of Marketing Research, 23(3), 237-249.

Holguín-Veras, J., Jaller, M., \& Wachtendorf, T. (2012a). Comparative performance of alternative humanitarian logistic structures after the Port-au-Prince earthquake: ACEs, PIEs, and CANs. Transportation Research Part A: Policy and Practice, 46(10), 1623-1640.

Holguín-Veras, J., Jaller, M., Van Wassenhove, L. N., Pérez, N., \& Wachtendorf, T. (2012b). On the unique features of post-disaster humanitarian logistics. Journal of Operations Management, 30(7-8), 494-506.

Holling, C. S. (1996). Engineering resilience versus ecological resilience. In P. E. Schulze (Ed.), Engineering within Ecological Constraints (pp. 31-43). Washington, DC: National Academy Press.

Holt, D., \& Littlewood, D. (2014). The informal economy as a route to market in Sub-Saharan Africa - Observations amongst Kenyan informal economy entrepreneurs. In S. Nwankwo, \& K. Ibeh (Eds.), The Routledge Companion to Business in Africa (pp. 198-217). London, UK: Routledge.

Hourani, A. (1991). A history of Arab peoples. New York: MJF Books.

Jahre, M., Kembro, J., Rezvanian, T., Ergun, O., Håpnes, S. J., \& Berling, P. (2016). Integrating supply chains for emergencies and ongoing operations in UNHCR. Journal of Operations Management, 45(1), 57-72.

Jones, R. (2016). Violent borders: Refugees and the right to move. London: Verso Books.

Khoury, T. A., \& Prasad, A. (2016). Entrepreneurship amid concurrent institutional constraints in less developed countries. Business and Society, 55(7), 934-969.

Kleinschmidt, K., \& Sy, S. (2016). New paradigms for refugee camps and for humanitarian aid itself. Carnegie Council for Ethics in International Affairs. Ethics Matter, Global Ethics Forum TV Series. Retrieved from https://www.carnegiecouncil.org/studio/multimedia/ 20160415-new-paradigms-for-refugee-camps-and-for-humanitarian-aid-itself. Accessed on 8 November 2019.

Kreibaum, M. (2016). Their suffering, our burden? How Congolese refugees affect the Ugandan population. World Development, 78, 262-287.

Lin, N. (2008). A network theory of social capital. In D. Castiglione, J. W. van Deth, \& W. Guglielmo (Eds.), The Handbook of Social Capital (pp. 50-69). New York: Oxford University Press.

Lincoln, Y., \& Guba, E. G. (1985). Naturalistic inquiry. CA: Sage Publications. 
Loescher, G. (2017). UNHCR's origins and early history: Agency, influence, and power in global refugee policy. Refuge: Canada's Journal of Refugees, 33(1), 77-86.

Mackenzie, C., McDowell, C., \& Pittaway, E. (2007). Beyond 'do no harm': The challenge of constructing ethical relationships in refugee research. Journal of Refugee Studies, 20(2), 299319.

Miles, M. B., \& Huberman, A. M. (1994). Qualitative data analysis: Grounded theory procedures and techniques. London, UK: Sage.

Nakagawa, Y., \& Shaw, R. (2004). Social capital: A missing link to disaster recovery. International Journal of Mass Emergencies and Disasters, 22(1), 5-34.

Novak, D., Wu, Z., \& Dooley, K. (2021). Whose resilience matters? Addressing issues of scale in supply chain resilience. Journal of Business Logistics, Forthcoming.

Obstfeld, O. (2005). Social networks, the tertius iungens orientation, and involvement in innovation. Administrative Science Quarterly, 50(1), 100-130.

Oka, R. (2011). Unlikely cities in the desert: The informal economy as causal agent for permanent "urban" sustainability in Kakuma Refugee Camp, Kenya. Urban Anthropology and Studies of Cultural Systems and World Economic Development, 40(3-4), 223-262.

Pacheco-Vega, R., \& Parizeau, K. (2018). Doubly engaged ethnography: Opportunities and challenges when working with vulnerable communities. The International Journal of Qualitative Methods, 17(1), 1-13.

Pathak, S., Wu, Z., \& Johnson, D. (2014). Towards a structural view of co-opetition in supply networks. Journal of Operations Management, 32(5), 245-267.

Pedraza-Martinez, A. J., \& Van Wassenhove L. N. (2016). Empirically grounded research in humanitarian operations management: The way forward. Journal of Operations Management. 45(1), 1-10.

Pilbeam, C., Alvarez, G., \& Wilson, H. (2012). The governance of supply networks: A systematic literature review. Supply Chain Management: An International Journal, 17(4), 358-376.

Prell, C. (2012). Social network analysis: History, theory and methodology. London: Sage.

Prost, A. (2006). The problem with 'rich refugees' sponsorship, capital, and the informal economy of Tibetan refugees. Modern Asian Studies, 40(1), 233-253.

Provan, K. G., Fish, A., \& Sydow, J. (2007). Interorganizational networks at the network level: A review of the empirical literature on whole networks. Journal of Management, 33(3), 479516.

Provan, K. G., \& Kennis, P. (2008). Modes of network governance: Structure, management, and effectiveness. Journal of Public Administration Research Theory, 18(2), 229-252.

Putnam, R. (2000). Bowling alone: The collapse and revival of American community. New York: Simon \& Schuster. 
Quarantelli, E. L. (1966). Organization under stress. In R. Brictson (Ed.), Symposium on Emergency Operations (pp. 3-20). Santa Monica, CA: Systems Development Corporation.

Quarantelli, E. L. (2005). A social science research agenda for the disasters of the 21 st century: Theoretical, methodological and empirical issues and their professional implementation. In R.W. Perry, \& E. L. Quarantelli (Eds.), What is a Disaster? New Answers to Old Questions (pp. 325-396). USA: International Research Committee on Disasters.

REACH (2014). Al Za'atari camp population profiling. Retrieved from https://reliefweb.int/sites/ reliefweb.int/files/resources/

REACH_AlZaatari\%20Camp\%20Population\%20Profile_April\%202014.pdf. Accessed on 22 November 2020.

Rodríguez, H., Trainor, J., \& Quarantelli, E. L. (2006). Rising to the challenges of a catastrophe: The emergent and prosocial behavior following Hurricane Katrina. The Annals of the American Academy of Political and Social Science, 604(1), 82-101.

Said, E. W. (1978). Orientalism. London: Pantheon Books.

Sanyal, R. (2012). Refugees and the city: An urban discussion. Geography Compass, 6(11), 633644.

Schuller, T., Baron, S., \& Field, J. (2000). Social capital: A review and a critique. In S. Baron, J. Field, \& T. Schuller (Eds.), Social Capital (pp. 1-38). Oxford: Oxford University Press.

Scott, J. C. (1998). Seeing like a state: How certain schemes to improve human condition have failed. New Haven, CT: Yale University Press.

Sendra, P., \& Sennett, R. (2020). Designing disorder: Experiments and disruptions in the city. London: Verso Books.

Shepherd, D. A., Saade, F. P., \& Wincent, J. (2020). How to circumvent adversity? Refugeeentrepreneurs' resilience in the face of substantial and persistent adversity. Journal of Business Venturing, 35(4), 105940.

Sodhi, M. (2016). Natural disasters, the economy and population vulnerability as a vicious cycle with exogenous hazards. Journal of Operations Management, 45, 101-113.

Starr, M. K., \& Van Wassenhove, L. N. (2014). Introduction to the special issue on humanitarian operations and crisis management. Production and Operations Management, 23(6), 925-937.

Strauss, A., \& Corbin, J. (1990). Basics of qualitative research: Grounded theory procedures and techniques. London: Sage Publications.

Szreter, S., \& Woolcock, M. (2004). Health by association? Social capital, social theory, and the political economy of public health. International Journal of Epidemiology, 33(4), 650-667.

Tatsuki, S. (2008). The role of civil society for long-term life recovery from a megadisaster. Paper prepared for the 2008 Annual Meeting of the American Political Science Association. Boston, MA: American Political Science Association. 
Taylor, J. E., Filipski, M. J., Alloush, M., Gupta, A., Valdes, R. I. R., \& Gonzalez-Estrada, E. (2016). Economic impact of refugees. Proceedings of the National Academy of Sciences, 113(27), 7449-7453.

Temple, B., \& Edwards, R. (2002). Interpreters/translators and cross-language research: Reflexivity and border crossings. International Journal of Qualitative Methods, 1(2), 1-12.

The New Humanitarian (2013). تكلفة_استضافة_اللاجئين_السوريين: Retrieved from https:// www.thenewhumanitarian.org/ar/report/3999. Accessed on 20 November 2020.

Turner, S. (2005). Suspended spaces - contesting sovereignties in a refugee camp. In T. B. Hansen, \& F. Stepputat (Eds.), Sovereign bodies: Citizens, migrants, and states in the postcolonial world (pp. 312-332). Princeton, NJ: Princeton University Press.

UNDP (2015). The impact of humanitarian aid on Lebanese economy. Retrieved from https:// www.undp.org/content/dam/lebanon/docs/CrisisPreventionRecovery/Publications/ Impact\%20of\%20Humanitarian\%20Aid-UNDP-UNHCR.PDF. Accessed on 17 June 2019.

UNHCR (2009). Media advisory: Half of the world's refugees now live in cities. Retrieved from http://www.unhcr.org/4b1cda0e9.html. Accessed on 8 December 2019.

UNHCR (2017). Economic inclusion of refugees in Rwanda: A strategy for furthering economic development in Rwanda through refugee self-reliance (2016-2020). Retrieved from http:// www.unhcr.org/rw/wp-content/uploads/sites/4/2017/02/Economic-Inclusion-of-Refugees-inRwanda-Final-Version.pdf. Accessed on 30 November 2020

UNHCR (2018a). The 1951 Convention and its 1967 protocol relating to the status of refugees. Retrieved from http://www.unhcr.org/about-us/background/4ec262df9/1951-conventionrelating-status-refugees-its-1967-protocol.html. Accessed on 18 November 2018.

UNHCR (2018b). Dadaab refugee complex. Retrieved from http://www.unhcr.org/ke/dadaabrefugee-complex. Accessed on 16 November 2018.

UNHCR (2018c). UNHCR Jordan factsheet - February 2018. Retrieved from https:// reliefweb.int/report/jordan/unhcr-jordan-factsheet-february-2018. Accessed on 17 June 2019.

UNRWA (2018). Palestine refugees. Retrieved from https://www.unrwa.org/palestine-refugees. Accessed on 16 November 2018.

Villena, V. H., \& Gioia, D. A. (2018). On the riskiness of lower-tier suppliers: Managing sustainability in supply networks. Journal of Operations Management, 64, 65-87.

Webb, J. W., Tihanyi, L., Ireland, R. D., \& Sirmon, D. G. (2009). You say illegal, I say legitimate: Entrepreneurship in the informal economy. Academy of Management Review, 34(3), 492-510.

Webb, J. W., Khoury, T. A., \& Hitt, M. (2020). The influence of formal and informal institutional voids on entrepreneurship. Entrepreneurship Theory and Practice, 44(3), 504-526.

Werker, E. (2007). Refugee camp economies. Journal of Refugee Studies, 20(3), 461-480. 
Williams, C. C., \& Shahid, M. S. (2016) Informal entrepreneurship and institutional theory: Explaining the varying degrees of (in)formalization of entrepreneurs in Pakistan. Entrepreneurship \& Regional Development, 28(1-2), 1-25.

Wilson, T. D. (2018). The informal economy and social programs in Mexico: A critique. Latin American Perspectives, 45(1), 130-145.

Woolcock, M. (2002). Social capital in theory and practice: Reducing poverty by building partnerships between states, markets and civil society. In UNESCO (Eds.), Social Capital and Poverty Reduction: Which Role for Civil Society Organizations and the State? (pp. 20-44). Paris: UNESCO.

Wu, Z., \& Pullman, M. E. (2015). Cultural embeddedness in supply networks. Journal of Operations Management, 37(1), 45-58.

Yin, R. K. (1994). Case study research: Design and methods (2nd ed.). Newbury Park, CA: Sage Publications. 


\section{Appendix A. Interview Protocol}

Focal areas for each interview, with specific questions customized during the interview and follow-up questions added when necessary.

\section{All Interviewees}

- Project explained, including policies for using interviewee information and for interviewees withdrawing interview data at any time.

- Personal background requested, including profession and personal history in Syria/Jordan.

\section{Refugees}

- Time of arrival at the Za'atari refugee camp, the nature of the journey, and precipitating events in home country.

- Camp life, including settling into camp existence and day-to-day social activities.

- Relationships, including families inside/outside the camp, clan ties, and new relationships through marriages or friendships.

- Economic activities (i.e., buying and selling).

- Perception of life and existence in the camp.

- Perception of relief agencies and camp authorities.

\section{Residents in Mafraq Host Community}

- Connections with refugees in the Za'atari refugee camp.

- Business activities (i.e., actual or observed) in the camp.

- Economic and social impact of the camp on the host community.

\section{IGOs/NGOs and the Jordanian Government}

- Overview of tasks and responsibilities, and the organization.

- Business and operational model of the organization.

- History, role/function, and daily work in the camp.

- Evolution of organizational relief strategy and tasks in the Za'atari refugee camp.

- Interactions and coordination with other actors (i.e., individuals and organizations).

- Conflicts, competition, and challenges in working with other actors. 


\section{Appendix B. Reference List of the Interviewees Quoted in the Study}

Format for each interviewee: title, actor group, month and year, location.

- Camp Former Director \#1, IGO, September 2017, Amman

- Camp Former Director \#2, IGO, December 2017, Teleconference Call

- Temporary Worker at Community Center, NGO-A, Refugee, November 2017, Za'atari refugee camp

- Restaurant Owner, Refugee, August 2016, Za'atari refugee camp

- Grocery Retailer, Refugee, August 2016, Za'atari refugee camp

- Bedouin Refugee, Refugee, October 2017, Za'atari refugee camp

- Unemployed Refugee, Refugee, August 2016, Za'atari refugee camp

- Supply Chain Officer, UNHCR, IGO, February 2016, Za'atari refugee camp

- Camp Site Supervisor, NGO-C, NGO, October 2017, Za'atari refugee camp

- Child Protection Officer \#1, NGO-B, NGO, September 2016, Amman

- Dairy Products Seller, Refugee, August 2016, Za'atari refugee camp

- University Student, Refugee, October 2017, Za'atari refugee camp

- Camp Court Lawyer, Government, August 2016, Za'atari refugee camp

- Supermarket Cashier, Host Community, April 2018, City of Mafraq

- Community Police Officer \#2, Government, September 2016, Za'atari refugee camp

- Government Official \#1, Ministry of Interior, Government, December 2016, Amman

- Relief Worker, NGO-D, NGO, February 2016, Amman

- Perfume Shop Owner, Refugee, August 2016, Za'atari refugee camp 